Florida International University FIU Digital Commons

FIU Electronic Theses and Dissertations

University Graduate School

11-15-2017

\title{
A Historical Floristic Inventory of Pine Rockland Fabaceae (Leguminosae)
}

Adel L. Pena

Florida International University, apena003@fiu.edu

DOI: $10.25148 /$ etd.FIDC004039

Follow this and additional works at: https://digitalcommons.fiu.edu/etd

Part of the Biodiversity Commons, Biology Commons, Ecology and Evolutionary Biology Commons, Forest Biology Commons, History Commons, Museum Studies Commons, and the Plant Sciences Commons

\section{Recommended Citation}

Pena, Adel L., "A Historical Floristic Inventory of Pine Rockland Fabaceae (Leguminosae)" (2017). FIU Electronic Theses and Dissertations. 3527.

https://digitalcommons.fiu.edu/etd/3527

This work is brought to you for free and open access by the University Graduate School at FIU Digital Commons. It has been accepted for inclusion in FIU Electronic Theses and Dissertations by an authorized administrator of FIU Digital Commons. For more information, please contact dcc@fiu.edu. 


\section{FLORIDA INTERNATIONAL UNIVERISTY}

Miami, Florida

\section{A HISTORICAL FLORISTIC INVENTORY OF PINE ROCKLAND FABACEAE (LEGUMINOSAE)}

A thesis submitted in partial fulfillment of

the requirements for the degree of

MASTER OF SCIENCE

in

ENVIRONMENTAL STUDIES

by

Adel L. Peña

2017 
To: Dean Michael R. Heithaus

College of Arts, Sciences and Education

This thesis, written by Adel L. Peña, and entitled A Historical Floristic Inventory of Pine Rockland Fabaceae (Leguminosae), having been approved in respect to style and intellectual content, is referred to you for judgment.

We have read this thesis and recommend that it be approved.

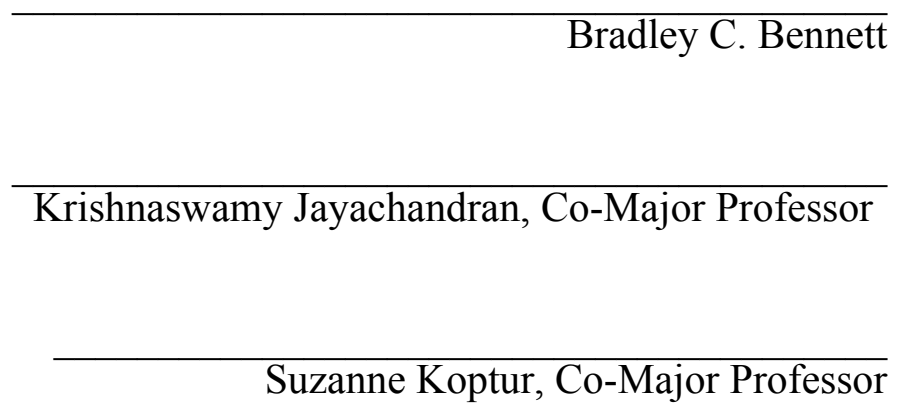

Date of Defense: November 15, 2017

The thesis of Adel L. Peña is approved.

Dean Michael R. Heithaus

College of Arts, Sciences and Education

Andrés G. Gil Vice President for Research and Economic Development and Dean of the University Graduate School

Florida International University, 2017 


\section{ACKNOWLEDGMENTS}

I would like to first thank my mother, Cleo Peña, for supporting me in the pursuit of this degree. I would also like to acknowledge members of the committee Drs. Suzanne Koptur, Bradley Bennett, and Krishnaswamy Jayachandran for support, guidance, and feedback. I would specifically like to thank Dr. Koptur and Dr. Bennett for helping shape my education and interest in botany, and Dr. Jayachandran for helping fund this research. I would also like to acknowledge herbarium curators Anthony R. Brack and Brett Jestrow for offering helpful suggestions and helping me navigate through their collections. Scott Zona and Jay Sah also provided helpful insight and suggestions. I would like to thank members of the Koptur lab and friends: Andrea Salas, Brittany Harris, Jaeson Clayborn, Cleo Pimenta, Jimena Valdes, David Berthold, Mustafa Sikder, who provided comradery and moral support through this process and Samantha Qyyum for providing research assistance. Lastly, I would like to thank FIU's College of Arts, Sciences and Education department of Earth and Environment for providing travel funding. 


\author{
ABSTRACT OF THE THESIS \\ A HISTORICAL FLORISTIC INVENTORY OF PINE ROCKLAND FABACEAE \\ (LEGUMINOSAE) \\ by \\ Adel L. Peña
}

Florida International University, 2017

Miami, Florida

Professor Suzanne Koptur, Co-Major Professor

Professor Krishnaswamy Jayachandran, Co-Major Professor

The objectives of this study were to investigate temporal changes in the diversity of pine rockland Fabaceae, induced by anthropogenic factors. Herbarium collections spanning 170 years were used to analyze species frequency and richness. The results indicated temporal fluctuations in diversity with frequency of native species highest previous to the year 1920, and exotic-invasive species richness peaking after the 1960s. The accompanying species list resulting from the inventory included 122 Fabaceae species, in 56 genera, with an additional 19 species not previously listed for pine rocklands. The results emphasize the damage caused by early and deliberate introductions of exotic species, and reinforces previous knowledge that exotic-invasives seem to be increasingly harmful to local biodiversity. The results also provide evidence of the historical distribution of species, helpful to conservation and restoration efforts. This study provides a needed review and status update for the Fabaceae taxa of the pine rocklands. 


\section{TABLE OF CONTENTS}

CHAPTER

PAGE

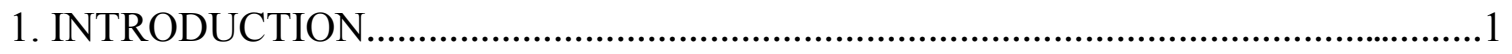

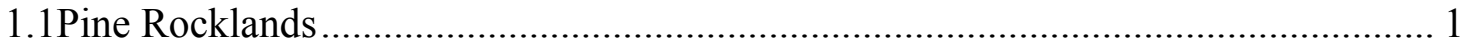

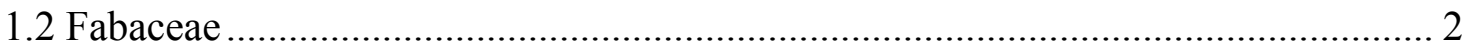

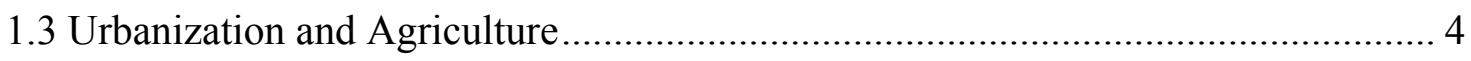

1.4 South Florida Development .......................................................................... 5

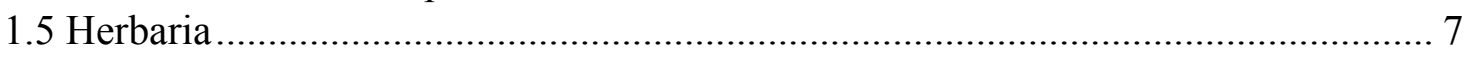

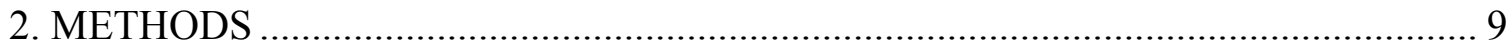

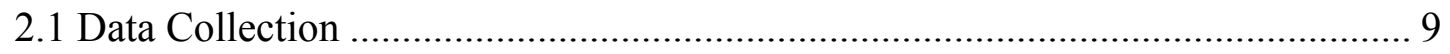

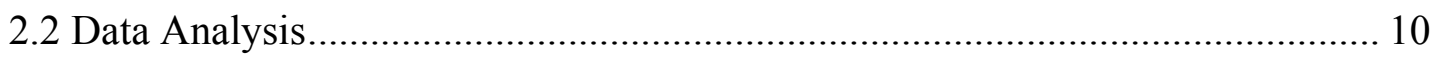

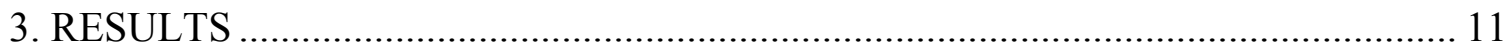

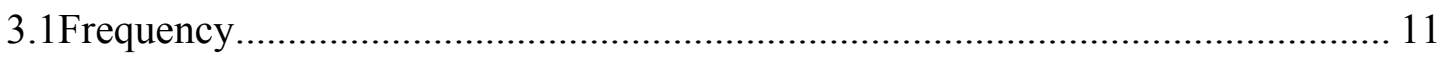

3.2 Human Population Growth .............................................................................. 12

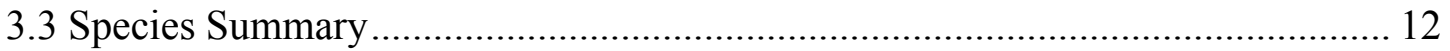

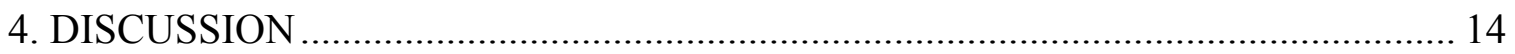

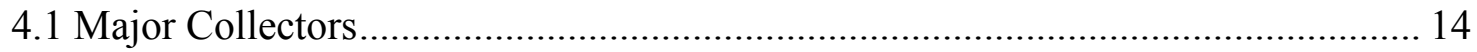

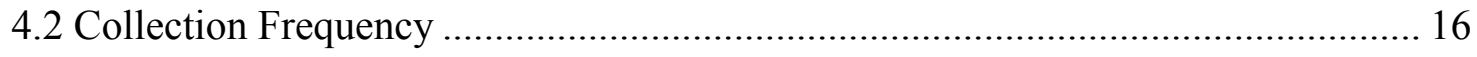

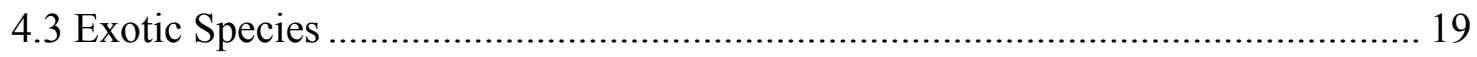

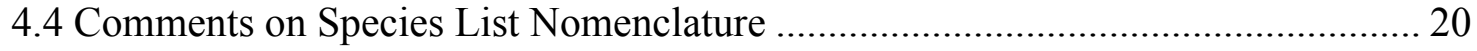

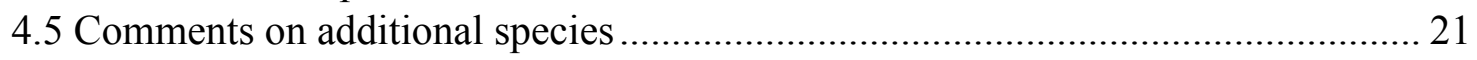

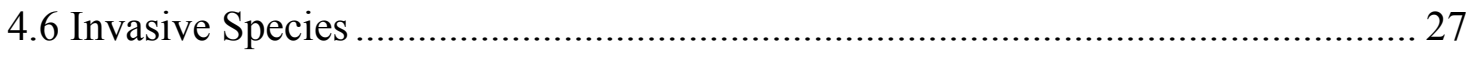

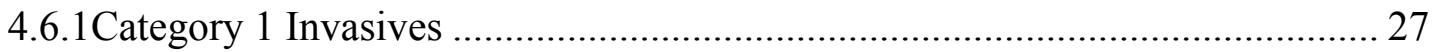

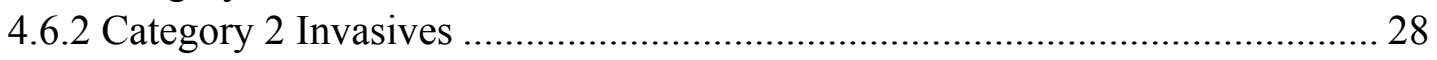

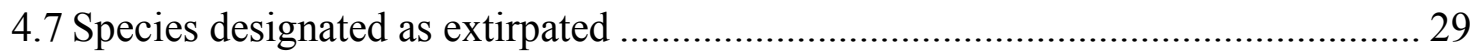

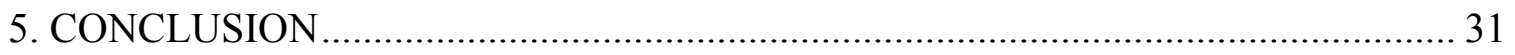

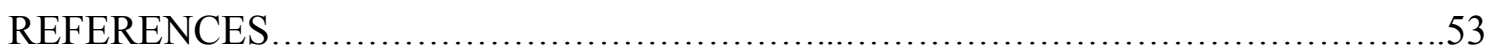

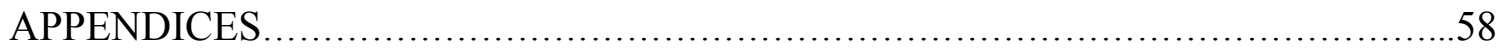




\section{LIST OF FIGURES}

FIGURE

PAGE

Figure 1 Estimated collections richness for all species for the decades of $1830-2010 \ldots . .41$

Figure 2 Estimated collections richness for native species for decades of $1830-2010 \ldots . .42$

Figure 3 Estimated collections richness for non-native species for the decades of 18302010

Figure 4 Proportional Collection Frequency (PFC) for native and non-native species for the decades of $1830-2010$.

Figure 5 Shannon's diversity index $(\mathrm{H})$ and Shannon's equitability index for the decades

of $1830-2010$

Figure 6 Human population increase for Miami-Dade, Monroe, and Collier counties for the decades of $1830-2010$.

Figure 7 Human population rates of increase for Miami-Dade, Monroe, and Collier counties for the decades of 1830-2010

Figure 8 Proportional collection frequency for I. miniata from 1830-2010. .48

Figure 9 Proportional collection frequency for N. pubescens from 1830-2010

Figure 10 Proportional collection frequency for R. reniformis from 1830-2010 .50

Figure 11 Proportional collection frequency for S. ligustrina from 1830-2010. 
Figure 12 Proportional collection frequency for D. carthagenensis var. floridana from

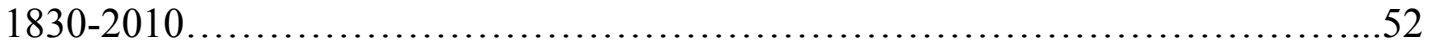




\section{INTRODUCTION}

\subsection{Pine Rocklands}

The pine rocklands are dry upland forests unique to southern Florida and the Bahamas. Characteristics of the pine rockland habitat include a rocky limestone substrate, which supports Pinus elliotti var. densa (slash pine) as the dominant canopy species, along with a diverse understory of herbs, palms, and shrubs (Snyder et al. 1990). Examples of the rich understory include the federally endangered Galactia smallii (Small's milkpea), and the IUCN red listed Amorpha crenulata (crenulate lead-plant), both members of the Fabaceae family. Approximately 532 species are documented for the pine rocklands (Gann et. al 2001), of which 31 are endemic to Florida (Powell and Maschinski 2012). Pine rocklands are a fire-successional habitat strongly associated with rockland hammock communities as pine rocklands can succeed into hardwood hammocks if not maintained by fire (Snyder et al. 2005). Prairies (finger glades) and mangroves are also associated communities which border pine rocklands (Snyder et al. 1990) particularly within Everglades National Park (ENP) and in the Florida Keys (Snyder et al. 1990, Lodge 2010), meaning there is sometimes overlap in vegetation and associated species with these adjacent habitats.

The historical distribution of pine rockland occurs along the Miami Atlantic ridge in Miami-Dade, Monroe County in the Florida Keys, and in the southeastern portion of Big Cypress (BICY) in Collier County (Snyder et al. 1990). There is some contrast among the different pine rockland regions mainly due to the substrate, elevation, and flooding. In Miami-Dade County they occur on outcroppings of Miami Limestone and 
tend to be highest in elevation, although overall elevation decreases towards the south with lower elevations and occasional flooding inside ENP (Snyder et al. 1990, Saha et al. 2011). Pinelands in the keys are found on Key Largo Limestone in Big Pine Key (BPK), where it also transitions into Miami limestone and continues in Little Pine, No Name, Cudjoe, and Sugarloaf Keys (Snyder et al. 1990, Bradley and Saha 2009). There is also evidence that suggest they may have also occurred on Key Largo (Alexander 1953). Pinelands in the Keys have an elevation of only $1-2 \mathrm{~m}$ above sea level and are occasionally inundated by salt water (Ross et al. 1994). In BICY, rocky pinelands occur over Tamiami Limestone, interspersed with cypress strands, and are covered during wet season months with fresh water. These pinelands tend to be sandier than Miami-Dade pine rocklands and have some flora in common with the more northern pine flatwoods (Snyder et al. 1990). As such, there is some skepticism as to the true nature of the rocky pines in the BICY area. However, in general they seem to be rather sparse and mainly restricted to the areas known as Pinecrest, Lostman's Pines, and Raccoon Point (Snyder et al. 1990).

\subsection{Fabaceae}

Fabaceae is the third largest family of flowering plants, encompassing 770 genera and approximately 19,500 species worldwide (Azani et al. 2017). The family is widely distributed, although its members occur mainly in tropical habitats (Legume Phylogeny Working Group 2013). Peanuts, soy, peas, and beans are some of the staple crops belonging to Fabaceae, making it one of the most economically important of the plant families (Bennett 2011). In addition to being a food source, species in the Fabaceae 
contains alkaloid compounds (Bennett 2011) and are the second largest medicinal plant family (Gao et al. 2010).

The wide range of diversity within Fabaceae also makes them important in ecological communities. Species occur in a variety of life forms, from trees to vines, shrubs, herbs, and lianas (Azani et al. 2017). Many papilionoid and mimosoid taxa can fix nitrogen, important to surviving in habitats with nutrient-poor soils. Great diversity is also exhibited in the flowers, but the unifying characteristics of the family are the fruit and leaves. The fruits are generally legumes, formed from a single ovary that can open along two sides (an alternative name for the family is Leguminosae), and atypically a samara (Cercidoideae, Detarioideae, Dialioideae) or drupe (Dialioideae, Papilionoideae) (Azani et al. 2017). Leaves of members of the family are usually compound, although characteristics vary by subfamily and even within lower taxa.

Traditionally, the family has been split into 3 subfamilies: Caesalpinioideae, Mimosoideae, and Faboideae (Papilionoideae), based on floral morphology, such as a pattern of aestivation and symmetry. Taxon delimitation for the family has been hotly debated over the years, with some researchers favoring 3 distinct families instead of 3 subfamilies (Lewis and Schrire 2003).At the writing of this thesis, the latest phylogenetic updates, have now split the family into 6 subfamilies. The new classification molecular data, and morphological characteristics. The 6 subfamilies are: Cercidoideae, Detarioideae, Duparquetioideae, Dialioideae, Papilionoideae, and Caesalpinioideae. The Mimosoideae are now embedded with Caesalpinioideae and deemed the mimosoid clade pending further classification (Azani et al. 2017). In terms of South Florida pine 
rocklands, only Bauhinia and Tamarindus, both exotic genera, fall into the new Cercidoideae, and Detarioideae, respectively. All native pine rockland genera currently belong to Caesalpinioideae (including mimosoid clade) or Faboideae.

In general, the characteristics observed in Fabaceae naturally occurring in Southern Florida are largely representative of the 3 original subfamilies and their descriptions. The Caesalpinioideae flowers are zygomorphic, usually have 5 petals with 5-10 visible stamens. The leaves are compound, even or odd-pinnate, and the habit can be tree, shrub, or an herb (Gagnon et al. 2016) and mimosoid clade flowers are actinomorphic and arranged in an inflorescence (head or spike), with even-pinnately compound leaves; with the habit ranging from herb to shrub to tree (Azani et al. 2017). Faboideae (Papilionoideae) is the largest of the subfamilies and from where most of the agricultural crops derive. The Faboideae also have a wider distribution as compared to the other subfamilies occurring in more temperate climates. They tend to have zygomorphic flowers, with 5 petals arranged in a standard-wing-keel arrangement with the top petal being the largest, 2 lateral petals, and 2 at the base. Their leaves are once compound, pinnate or palmate, and habit spans a wider range: tree, shrub or, herb, or vine (Azani et al. 2017).

\subsection{Urbanization and Agriculture}

Major issues affecting landscapes of developing countries have continually been the conversion of natural habitats into urban and agricultural land. According to the U.N. Food and Agriculture Organization (FAO), approximately 18 acres of natural land are deforested for agricultural use every year. Urban areas, land purposed for residential and 
commercial use, contain $54 \%$ of the world's population (WHO). In the U.S. the number increases to $80 \%$. The resulting effects of urban development vary, with the most direct and immediate effect being habitat loss. Habitat loss resulting from urban development is considered especially harmful to natural areas, as it causes more drastic changes than land converted for agricultural use. Other documented effects of land conversion include changes to biogeochemical cycles, hydrology, changes to plant-animal interactions, and an increase in the number of exotic species (Knapp et al. 2010). Exotic species, mainly sourced from the horticulture and landscape market (Pemberton and Liu 2009), result in biotic homogenization (Knapp et al. 2010).

\subsection{South Florida Development}

The history of development of South Florida is relatively recent compared to much of the United States. Development occurred in a short and rapid amount of time, catalyzed by Flagler's extension of the railroad in 1896 . Until the late 1890s, the region remained mostly wilderness, even with early known pioneers and established historical areas such as Coconut Grove, Buena Vista, Lemon City, and Little River, built mainly over high and dry rocky pineland (Bingham 1948). The first 2 decades of the 1900s saw a constant and large influx of new settlers in the area, as development and agriculture over pinelands moved south-west with time. Population rose even more rapidly with the Florida Land Boom of the 1920s, which attracted thousands to the FL real-estate market (Tebeau et al. 1999). During this time, George Merrick was also building Coral Gables over prime rockland forested area. However, pinelands south-west of Miami and the Keys remained mostly undeveloped until after the Second World War. 
Agriculture was an early draw for many settlers, as they could grow crops in the south Florida climate while northern areas were under snow in winter. Miami and points heading south to Perrine, Goulds, Princeton, Naranja, and Florida City were converted for agricultural use before eventually being developed for housing (Dambaugh 1962). Southern Florida continued to attract more tourists, leading to extensive development in Monroe County, whose use of the fresh water reserves may have incited vegetation change as the freshwater below the land turned more salty, and pine forests disappeared from the northern Key Largo (Ross et al. 1994). The population rose rapidly, first in Miami, then further south and west. The BICY area in Collier County was a center for the logging of both cypress and pine trees between 1900 and 1960 (Tebeau et al. 1999), which contributed to habitat loss, although historically the area was never highly populated (Figure 7). The warm climate and coastal proximity has continued to make south Florida a target destination attractive to both tourists and new settlers from all over the world. Statistics indicate the current population for Miami-Dade is approximately 2.7 million and is projected to increase by 700,000 in the next 10 years (EPA 2016). South Florida also takes the lead for the importation of invasive and exotic plants in the continental U.S.

Most of the remaining and more intact pinelands are currently located inside of protected areas in ENP, BICY, and Key Deer National Refuge in BPK. Outside of protected areas, many small fragments of the pine rocklands remain, parts of a former continuum now are severely fragmented as a result of anthropogenic habitat eradication. Small fragments result in small and isolated populations of plants and animals, which can limit gene flow (Geiger et al. 2014). In addition to development, invading species such as 
Schinus terebinthifolius (Brazilian pepper), found in most pine land fragments, aggressively compete for space. Fire suppression is the third major issue affecting pine rockland communities since without fires the pine forests succeed to hardwood hammocks (Snyder et al. 2005). Urban development interferes with fire regimes needed to maintain diversity, control invasives, and prevent succession to hardwood forests.

\subsection{Herbaria}

Despite the long-term issues brought by urbanization and agriculture, there have not been studies detailing these effects on local flora over long periods of time. This study will analyze the anthropogenic effects on pine rockland Fabaceae over 100+ years. The methods that I propose involve the use of historical data stemming from herbarium specimens along with any accompanying archival records. Specimens provide a plethora of information by way of type and voucher specimens, as well as catalog information. There are, however, some known biases associated with herbaria. Over time, collections can suffer from misidentification, inconsistent collecting, or oversampling of certain species (Lavoie 2013). There is also a correlation between the number of collections, botanical gardens, and universities known as the 'botanist effect (Moerman and Estabrook 2006), where the number of specimens collected in a certain area, increases with the number of research institutions. More attractive or ornate species may also be favored, while those species more difficult to collect are avoided and therefore underrepresented. Nevertheless, herbarium collections are incredibly useful for facilitating research. Herbarium specimens are used as reference for species verification and taxonomic studies (Lavoie 2013). They serve as historical evidence of the existence 
of species, and can, therefore, also be used to effectively analyze biodiversity via historical floristic assessments (Dolan et al. 2011, Dolan et al. 2011, Chocholoušková and Pyšek 2003). They are also used to study the history of colonization by exotic species, patterns of invasiveness, and climate change. Fuentes et al. (2008) traced the spread of invasive species back to Colonial settlers and periods of intense agriculture in Chile using herbarium collections, and changes in Boston flora induced by climate change were revealed using herbarium records dating back to 1885 (Primack et al. 2004).

For the purpose of this project, I conducted a historical floristic inventory of pine rockland Fabaceae in order to examine changes in the flora, as a result of human influences over the last centuries. I chose to focus on Fabaceae because it is a large, globally important family, well-represented in pine rocklands. This research project sought to answer the following questions: (1) Are temporal changes in diversity (richness and evenness) of pine rockland Fabaceae spp. detectable using historical herbarium data? 2) If changes are detectable, can these be correlated with local population growth? (3) Are there any detectable patterns in extinctions or introduced species and 4) Can this method be used to meaningfully portray changes in natural habitats over time? 


\section{METHODS}

\subsection{Data Collection}

I compiled a preliminary list of Fabaceae species recorded for the pine rocklands using several sources: The Floristic Inventory of South Florida Database Online (FISF) (http://www.regionalconservation.org/ircs/database/database.asp), Guide to the Vascular Plants of Florida, 3rd Edition (Wunderlin and Hansen 2011), and Vascular Flora of the Southeastern United States: Leguminosae (Isley 1990). Next, a herbarium record inventory was conducted targeting Fabaceae collections originating in the geographic areas of known historic distribution of pine rocklands: Miami-Dade, Monroe, and Collier counties. A physical inventory was conducted at (1) The William and Lynda Steere Herbarium at New York Botanical Garden (NYBG), which includes the Brooklyn Museum Herbarium (BKL); (2), Harvard University Herbaria (HUH) and (3) The Fairchild Herbarium at Fairchild Tropical Gardens (FTG), which includes the former Florida Atlantic University Herbarium (FAU). Additional herbarium data were obtained from databases belonging to South Florida Collections Management Center at Everglades National Park (SFCMC), and online databases belonging to the Robert K. Godfrey Herbarium at Florida State University (FSU), the National Herbarium at Smithsonian $(\mathrm{NMNH})$, the University of Florida Herbarium (FLAS), the University of Florida Plant Atlas, and Royal Botanic Gardens (Kew). A second species list resulting from the inventory was compiled, noting species name, habitat, county, year collected, and collector, using the label data included with each specimen. I assumed label data were correct and targeted only those specimens originating from the historical distribution of 
pine rocklands, and those collectors who identified the habitat as pine rockland (or some variation of the name), or those who included a general habitat description along with a known locality.

Species nomenclature was determined using Wunderlin and Hansen's Guide to the Vascular Plants of Florida, 3rd Edition, The Plant List (http://www.theplantlist.org), International Legume Database Information System (ILDIS) (https://www.Ildis.org), and the Integrated Taxonomic Information System (ITIS) ( https://www.itis.gov). The Florida Pest Plant Councils' (FLEPPC) invasive species list was used to verify invasive status. The Endangered Species Act (ESA), published by the U.S. Fish and Wildlife Service was used to determine federal and state conservation status, and the International Union for Conservation of Nature (IUCN) for Red List status. South Florida human population data were obtained from records published by the U.S. Census Bureau.

\subsection{Data analysis}

The resulting inventory list was used to determine species richness (S). Shannon's diversity index was calculated using the formula $\mathrm{H}=-\sum$ ( $\mathrm{Pi}$ * $\left.\ln \mathrm{Pi}\right)$ and Shannon's equitability index was calculated using $\mathrm{EH}=\mathrm{H} / \mathrm{Hmax}=\mathrm{H} / \mathrm{lnS}$. Percent frequency for each species was calculated as $\%=\mathrm{f} / \mathrm{N} \times 100$, where $\mathrm{N}=$ the number of specimens. 


\section{RESULTS}

A total of 1339 records were used in the analysis for this study, with specimens spanning years from 1830 through 2015. Collier County accounted for less than 1\% of diversity in specimens, 73\% were from Miami-Dade, and 26\% from Monroe. Temporal changes in diversity were apparent from the herbarium data. Overall diversity fluctuated over time, with peaks in species richness during the decades of 1900-1920, 1960-1970, and 1990s (Figure 1). Richness for native Fabaceae was highest during 1910-1920 and 1990s (Figure 2). Richness for non-native Fabaceae was highest 1960-1970s and 1990s (Figure 3).

\subsection{Frequency}

The proportional collection frequencies (PCFs) were highest for all species in the decades beginning in 1910, 1960, 1970, and 1990. Native PCF was highest in 1910 and non-native PCF was highest in 1960 (Figure 4). The species with the highest frequency of collections overall was the distinctive Rhynchosia reniformis (Table 2). The most collected species (those with greatest number of specimens) were Chamaecrista lineata var. keyensis, Crotalaria rotundifolia, Indigofera miniata (Figure 8), and Rhynchosia reniformis (Figure10). These are also among some of the most consistently collected (10 or more decades of collections), except for I. miniata, along with Chamaecrista fasciculata, Chamaecrista nictitans var. aspera, Crotalaria pumila, Neptunia pubescens (Table 1), Rhynchosia cinera, Rhynchosia minima, Rhynchosia reniformis, and Senna mexicana var. chapmanii (Table 1). Six species (Dalea carthagenensis var. floridana (Figure 12), Indigofera miniata, Neptunia pubescens, Rhyncosia reniformis, Senna 
ligustrina (Figure 11), and Neptunia pubescens) decreased in frequency. Four species (Crotolaria pumila, Desmodium lineatum, Stylosanthes hamata, and Galactiai smallii) increased in frequency over the course of the collections (Table 1, 4). Two species were not present in the collected herbarium data: Desmodium paniculatum and Tephrosia chrysophylla, although both are listed as pine rockland species.

\subsection{Human Population Growth}

Human population statistics from the U.S. Census Bureau showed population for Miami-Dade and Collier counties increasing steadily over time for all counties, although Monroe experienced some slight fluctuations in population (Figure 6-7). Miami-Dade experienced exponential rates of change in population beginning with the 1880 s through 1930 , with a $475 \%$ increase going from the 1890 s into the 1900 s. Monroe population increased drastically in the 1840s (240\%) and 1940s (113\%). Human population in Collier County increased steadily over time.

\subsection{Species Summary}

Overall, the resulting list from the inventory contained 122 species, in 56 genera (Table 3 ). This was an increase of 19 additional native and 32 additional non-native species over those included in my preliminary list. Of all the specimens collected in Miami-Dade County, $87 \%$ of the collections were non-native species; for Monroe County, $12 \%$ of specimens collected were non-natives species. No exotics were represented in specimens collected in Collier County. Miami- Dade contains the majority of the invasive species. 
Fabaceae exotics found in pine rocklands originate from all over the globe, but most of the invasive legumes originate in Asia. The first exotic Fabaceae was recorded in 1903 for Miami (Crotolaria incana), while for Monroe County it was in 1830 (Caesalpinia pulcherrima). Six out of ten invasives are from Asia, and are mainly woody. Most were introduced from the horticultural market. Two invasives come from the genus Albizia. While there are some early records of non-natives, the majority are present in the specimen data mainly in the second half of the century.

Five legume species are currently listed as extinct or extirpated in the wild. Chamaecrista deeringiana and Galactia elliottii are no longer found in Monroe County; Desmodium floridanum has disappeared from Collier County, and Phaseolus polystachyus var. sinautus, and Tephrosia angustissima are gone from Miami-Dade. Most of these extirpated taxa are Faboideae, and were last recorded in the 1960s. 


\section{DISCUSSION}

This study attempted to gauge temporal changes in biodiversity of pine rockland Fabaceae using herbarium data. The study spanned the decades 1830 to 2015 and included 1330 specimens. There were some gaps in the collection, as no specimens used in this study originated from the decades of 1850 to 1870 , and there was also a significant decrease in collections between 1920 to 1960 .

Overall, the herbarium data exhibited fluctuations in richness over time, with peaks in richness in 1900-1920, 1960-1980, and the 1990s. Richness was shown to decrease between 1920-1960. There was no relationship between richness and human population size. Census data show a consistent increase in population over time beginning with the 1900s, whereas Fabaceae richness fluctuates over time. However, collection frequencies are highest in 1900 -1920 and 1960-1980 and 1990s. More specifically, the decades of $1910,1960,1970$, and 1990 produced the highest number of specimens (Figure 4), meaning the patterns in richness are likely more indicative of collection effort.

\subsection{Major Collectors}

The major collectors from this time were mainly involved in making floras. The major collector of Fabaceae specimens from the periods between 1900-1920 was John K. Small. Other frequent collectors during this time include Charles A. Mosier, Joel J. Carter, and George K. Small; all these collectors worked alongside J.K. Small. Small was the curator at NYBG until 1934 and was actively collecting with the goal of growing the collections of that institution. He was also updating his Flora of the Southeastern United 
States (Small and Rydberg 1913) which he revised in 1913 and 1933. Most of the specimens from the 1960s were collected by Olga K. Lakela who worked at USF to help grow the herbarium, and at the same time was co-authoring Flora of Tropical Florida (Long and Lakela 1976). Donovan S. Correll collected the most in the 1970s. He was a botanist who specialized in orchids but in the 1970s moved to Miami to work at FTG in order to study the Flora of Bahamas. He co-authored (with his wife Helen Correll) Flora of the Bahama archipelago (including the Turks and Caicos Islands) (Correll and Correll 1982). For the decade of the 1990s, Keith Bradley was the major collector while he contributed to the IRC Floristic Inventory.

The lack of collections predating 1900 may be the result of a number of different factors. Inaccessibility of habitats and hostile conditions may have deterred exploration. Southern Florida was still mainly wilderness until the turn of the century. In a letter to John Torrey in 1845, J.L. Blodgett, who resided in South Florida, described the difficulty of collecting here with "drenching rains", mosquitoes, and "120 degree heat" (Carlton 1953). Florida was also involved in three Seminole wars until the 1850 s, then the civil war in the 1860s had the south pre-occupied. Studies indicate botanical exploration as a whole is cyclical, and research activities (e.g., publications, expeditions, making of floras) usually decrease in between wars (Rich 2006). However, there were still active plant explorers pre-1900, like Alvin Chapman, Allan H. Curtiss, and John L. Blodgett. Perhaps poor record keeping or lack of interest in Fabaceae accounts for lack of data. Blodgett seemed to have a preference for Euphorbiaceae and Asteraceae as a great number of his specimens came from these families (Carlton1953). 
The decade of the 1920s was one of building and expansion,known as the period of the great Florida Land Boom (Tebeau et al. 1999). The 1930s to 1960s was a rather tumultuous period in history considering the Great Depression (1930s), World War II (1940s), and rebuilding in their aftermaths. While there were collecting activities midcentury, the country was rebuilding and an excess of funding for botanical explorations may have been scare. For example, we know that J.K. Small, one of the most prolific specimen collectors, was sponsored by the likes of Charles Deering and Arthur C. James. Nevertheless, an important caveat is that this study is focused on a single plant family. In order to really assess the patterns in herbarium collecting activity, all plant families would need to be surveyed.

\subsection{Collection Frequency}

While results of this study are strongly related to collection effort, and there are certainly a number of known biases associated with herbarium data, analyzing collection frequencies mitigates some bias in the data. Collection frequency can be correlated to frequency in nature, by highlighting gaps or patterns occurring over time (Hedenäs et al. 2002). In this particular study, when collection frequency data is examined a number of patterns begin to emerge, as seen with those species exhibiting either increasing or decreasing over time (Table 1). Similarly, Hedenas et al. (2002) calculated the collection frequency of 20 common Swedish moss species to gauge whether changes in frequency could be linked to environmental changes. While in this study I examine a greater number of species specific to one habitat, collection gaps and patterns provide a starting point for further inquiry which can be a useful tool for setting conservation priorities. 
Whether or not a species is collected is influenced by habits of the collectors, and these collecting habits are influenced by a number of factors. Some species are more accessible, e.g. those that occur on habitat edges or growing in the more open areas along trails. Edge habitats have increased over time with more habitat fragmentation;

Chamaecrista. nictitans is often found in somewhat disturbed sites, and so could be more common as a result of these changes. Crotolaria spp. are often observed along pineland edges (A. Peña, personal observations). Both $C$. pumila and $C$. rotundifolia are common species, as are most species belonging to the Faboideae subfamily. However, many of the most frequently collected species are found in various fragments around Miami-Dade, occurring in various terrestrial habitats outside of pine rocklands, and are widely distributed throughout the southern U.S. (Isley 1990; Wunderlin and Hansen 2011). Studies show there is an association between distribution and abundance (Brown 1984) which may also account for collection frequency.

There are also characteristics that employ greater plant fitness. Crotalaria spp. have projectile seeds that are secondarily dispersed by ants (Stamp 1990). Like many Caesalpinioideae, C. nictitans and S. mexicana var. chapmanii have extrafloral nectaries which may help increase reproductive fitness by attracting ants and other beneficial insects (Jones and Koptur 2015, Koptur et al. 2015). All these characteristics may have contributed to the abundance and persistence of these species over time.

In some instances, collector preference plays a role in collecting pattern. $G$. smallii and C. lineata var. keyensis are currently listed as endangered species, and may have been more common in previous years. It may be that the number of collections is a 
result of species being collected for their novelty or value as rare and endemic plants. Herbarium based studies indicate botanists tend to emphasize and over collect rare flora (Lavoie 2013, Garcillán and Ezcurra 2011). In addition, Possley et. al (2008) found $G$. smalli had a broad distribution in Miami-Dade pine land fragments, citing efficient conservation efforts on the part of local managers. There were, however, species whose collection frequency decreased over time (Figure 8-12). From this category, only $R$. reniformis and D. carthagenensis var. floridana are federally and state listed species (Appendix A). Rhynchosia reniformis occurs in pristine habitats, and so habitat change would explain its decrease in PCF over time (Figure 10). A survey of Madagascar's legumes indicated that 15 herbarium specimens were sufficient to determine species that were threatened with extinction as defined by IUCN criteria (Rivers et. al 2011). With the exception of $D$. carthagenensis var. floridana, the species indicating a decrease in PCF all include more than 15 specimens. However, the Madagascar study was based on a geographical survey, while my study was temporal. Desmodium paniculatum and Tephrosia chrysophylla (Appendix A) were not present in the collected data. According to Gann et al. (2002) T. chrysophylla was collected by Roy Woodbury in the Cutler and Ludlam pinelands in the 1940s, but has not otherwise been found or listed for MiamiDade. Neither species are listed for conservation, and their absence may be a result of nomenclature or misidentification issues. Ultimately, the species not already listed for conservation would need to be examined further, and surveyed in field sites in order to assess whether the decline in PCF, or absence in the herbarium data, is due to the species becoming increasingly rare or some random coincidence. 


\subsection{Exotic Species}

Other patterns in the data include the increased presence of non-native species in the second half of the twentieth century. While the earliest exotic recorded in the collection is from 1830, and there are several other early records of exotics, there is a pattern of increase with time, especially for Miami-Dade County. There may be a number of reasons to explain this phenomenon. Miami-Dade saw an increase in population growth going into the 1960s of $89 \%$, almost doubling numbers of human inhabitants from the previous decade (Figure 7). Increase in human population follows an increase in development for housing and landscaping, and most exotics are a product of the horticultural industry, which brings in many non-native species that escape cultivation (Reichard and White 2001). It is also possible that there was a concerted effort to collect exotic species during this time. The inventory indicates George N. Avery was the biggest collector of Fabaceae exotic species, followed by Olga Lakela, and Keith Bradley. Avery compiled several checklists of South Florida flora, as was the case for Lakela, and Bradley was involved in IRC's floristic inventory. However, I found no information about specific expeditions for the collection of non-native species. It is possible that exotics are over represented as a result of collectors focusing on new species, rather than those previously documented. Nevertheless, the increased collection frequencies may, in fact, be a result of the species spreading in natural and disturbed areas over time. Some studies suggest a lag time from introduction to invasion for woody species of 130-147 years (Niinemets and Peñuelas 2008). This theory is consistent with the time of 
introduction for most of the woody Fabaceae introduced before 1900 that have in turn become invasive.

Lastly, it is important to note the diversity within the collections. When using Shannon's $\mathrm{H}$ and $\mathrm{E}_{\mathrm{H}}$ the data show diverse and consistently even collections over the decades. In addition, there are more than to 200 collectors, which also helps decrease bias as more collectors increase the randomness of the data (Petersen and Meier 2003).

\subsection{Comments on Species List Nomenclature}

Nesom (2015) recently revised the genus Galactia. Results from my inventory show a total of 8 Galactia species. Commonly accepted Galactia occurring in pine rocklands include G. floridana, G. parvifolia, G. pinetorum, G. regularis, and G. smallii. My inventory adds 3 more; G. elliotti, G. striata, and G. volubilis. There have been issues relating to the nomenclature of $G$. regularis and G. volubilis, where some sources have used the two names for the same species. I am listing them as distinct species following Nemsom's revision.

I have included a discussion on the inclusion of the 19 additional species, said to have been collected in pine rocklands according to the results of my inventory. Exotic species escape cultivation for any numbers of reasons owing to their biology, and landscaping uses. There may also be a lag time between their introduction and their populations increasing. Therefore, I have not included a discussion on these. The additional species found post-inventory are likely adventive but some may be reconsidered for official pine rockland native status. I use the terms adventive to mean the 
species became naturalized into a new habitat through different modes of dispersal (Richardson et al. 2000), reproducing successfully but not outcompeting native species.

Conventional definitions designate a species as native if it grows naturally in a given region, or was present when the European explorers first made contact; in the case of Florida that was the early 1500s. However, recorded botanical history for southern Florida is not very extensive, especially when compared to the centuries of botanical collections from New England and most of Europe. There is also something to be said for ecological alterations caused by early man and indigenous people, although not as extensive as the post-Columbian eras, they still occurred (Webb 1985). Considering historical aspects of southern Florida, I think that the species list needs to be re-evaluated as we acquire more complete botanical records over time.

Thus, I have incorporated methods set by D.A. Webb (1985), in which eight criteria are employed to determine native status. The criteria include fossil evidence, historical evidence, habitat, geographical distribution, frequency of naturalization, genetics, reproduction, and means of introduction. Coile (2002) also includes the presence of associated species, such as insects as a sign of nativity. Not all criteria will apply in every situation, but it these present a good starting point when making decisions.

\subsection{Comments on additional species}

(1) Aeschynomene pratensis is a species usually associated with wetlands. It is also listed as occurring pinelands (Wunderlin and Hansen 2011), and Everglades pineland margins (Isley 1990). While there is an association with wetlands and pineland margins, there is little evidence suggesting this species was historically found in pine rocklands. 
(2) Amorpha fruticosa has no official listing for pine rocklands. It is listed as occurring in disturbed upland habitats by IRC, in hammocks and streams (Wunderlin and Hansen 2011) and in upland forests and pineland margins (Isley 1990). The species has been vouchered all over South Florida, but its frequent occurrence in disturbed habitats means is very likely locally adventive in pine rocklands rather than native.

(3) Canavalia rosea is a species usually associated with beach dunes and not listed by any sources as occurring in pine rocklands. I have one historical specimen (previous to 1960) collected in Miami. However, the label lacks specific information as to the vicinity of the pineland, therefore if correctly identified, this species is likely locally adventive.

(4) Desmodium incanum is listed as a non-native to Florida by various sources. According to ILDIS it is an introduced species native to the Caribbean, including Bahamas and Cuba. In Wunderlin's book it is listed as native to Old and New World Tropics. Isley lists it as an introduced species with pantropical distribution. However, IRC lists the species as a native based on the fact it was previously considered a native by several sources including Wunderlin and Hansen, and also on a Small specimen from 1933, putting it in hammocks. My inventory results confirm the presence $D$. incanum in pine rocklands over the years. The earliest records are from 1880s (Curtiss) and 1915 (Small) all cases recording it in pine rocklands. It is included in a checklist by Woodbury and Dickson from Big Pine Key from the 1950s (Dickson et al. 1953) placing it in Monroe County. While the data indicate some fluctuation in frequency, they do not show this taxon to be increasing over time, as if it were behaving like a recently introduced 
species. Also, collecting records of D. incanum go back to 1880 (Curtiss). Based on both its distribution and historical data, I conclude that showing it is a good candidate for official listing for pine rockland native Fabaceae.

(5) Dalea feayi is listed as native to Southern Florida and Miami-Dade by IRC. It is also listed as occurring in scrubby flatwoods (Wunderlin and Hansen 2011), and pinelands (Isley 1990). Although some scrubby flatwoods inhabit the northern portion of Miami-Dade, the specimens I observed were collected in southwestern Miami-Dade. Several historical records place this all over Florida, but not where that pine rocklands are found. Only the recent collections are from known pine rockland sites. All the specimens I have collected are modern and thus, this species is probably adventive rather than native to pine rocklands.

(6) Desmodium ciliare has no listing at all in IRC; it is listed as occurring in hammocks (Wunderlin and Hansen 2011), and open woodlands (Isley 1990). It is listed as native to the state of Florida. I have found no historical records of the species in pine rocklands, only modern ones. Thus, because of its weedy nature, it is more likely more adventive than native.

(7) Desmodium rigidum is a species native to Florida, but it is not listed for South Florida. Wunderland \& Hansen lists it as a hammocks species and Isley as general woodlands. I have collected several historical records from Small and Buswell which place $D$. rigidum in pine rocklands. However, these specimens have no annotations except name updates and need to be examined for verification. 
(8) Acaciella angustissima is a species native to Florida, but not previously listed as occurring in pine rocklands. According to Wunderlin and Hansen it occurs in disturbed areas, while in Isley it is listed as growing on limestone outcroppings but does not specifically list pine rocklands. The IRC inventory contains no listing for the species. My inventory resulted in only historical records for A. angustissima. The species is listed as a Florida endangered species. It is possible it was a rare species that may have disappeared over time, but more records would be needed for greater certainty.

(9) Galactia striata has no official listing for pine rocklands. It listed as growing in disturbed upland habitats (IRC), and coastal hammock (Wunderlin and Hansen 2011). However, Isley has it growing in pinelands and growing on limestone. It has been recorded in several pine rockland parks in Miami-Dade and I have several historical records also placing it in pine rocklands as early as 1906. Therefore, its distribution and historical data make it candidate for official pine rockland native listing.

(10) Galactia volubilis is listed as occurring in disturbed upland habitats (IRC), hammocks (Wunderlin and Hansen 2011), and woodlands and a variety of habitats (Isley 1990). It's difficult to say with certainty whether this is more adventive than native to pine rocklands on the basis of my data. The inventory resulted in several historical and modern specimens of G. volubilis collected from pine rocklands over the years and from a variety of collectors. However, its habitat tendencies for disturbed areas makes me doubt its nativity. Either way this should a candidate for further research. 
(11) Guilandina bonduc is listed as occurring in disturbed upland and rockland hammock (IRC), as coastal strand (Wunderlin and Hansen 2011), and mangroves and disturbed sites (Isley 1990). I collected only a single historical record of G. bonduc that puts sit in pine rocklands, although rockland hammocks and mangroves (Keys) are associated pine rocklands habitats.

(12) Indigofera caroliniana is native to Southern Florida, listed as disturbed upland (IRC), scrub (Wunderlin), pinelands, and pine-palmetto (Isley 1990). Few recent specimens place this species in pine rockland, so it may just be a rare species or possibly adventive.

(13) Pithecellobium unguis-cati is not listed as a pine rockland native, but is designated a species for both inland (IRC) and coastal hammock (Wunderlin and Hansen 2011). Isley lists it as a scrub species, but states it is sympatric with P. keyense in the Keys. I do not have many records of this species being collected in pine rockland, and it is likely an adventive species.

(14) Sesbania herbacea has no official listing for pine rocklands but it is associated with wetlands (IRC) and disturbed sites (Wunderlin and Hansen 2011); Isley has no listing. I only have one modern record of this taxon and it could be a result of wrong identification or indicate an adventive species.

(15) Sesbania vesicaria is listed as a disturbed wetland species (IRC), in disturbed sites (Wunderlin and Hansen 2011), and in fields and agricultural sites (Isely 1990). I have historical records collected by Small, specimens on which pinelands which have been annotated. Records show it has been vouchered through most of Florida. Sesbania 
species were found in a checklist from 1950s, and collected over time, including early records from Miami-Dade.

(16) Stylosanthes biflora has no official listing for pine rocklands. According to IRC, it only occurs in Lee County. Isley states it occurs in rocky or sandy woodlands and Wunderlin lists it for hammocks and sand hills in central and northern counties. My inventory revealed only one specimen from FLAS with no photo. Thus, it is possible the inclusion of this species is likely a result of misidentification.

(17) Stylosanthes hamata is listed as occurring in pinelands by Wunderlin, and Hansen by IRC as disturbed upland, with records being collected throughout Miami-Dade pine rockland remnants. Isley, however, places the species in pine-palmetto habitats and borders of hammocks, but questioned its nativity. The species has been collected throughout the decades, and the oldest record I found is from a checklist from the 1950s, and the herbarium data indicate its frequency is increasing.

(18) Sophora tomentosa var. truncata is generally listed for hammocks. Many records exist of the species in pine rocklands, and I have personally observed it along the edges and in more disturbed pine rockland sites and the species should be included with pine rockland species.

(19) Vicia acutifolia is listed as occurring in wet hammocks and disturbed sites (Wunderlin and Hansen 2011) and disturbed wetland by IRC. While I do not have any historical records of the species, it has been recorded in several Miami-Dade parks where pine rocklands occur. 


\subsection{Invasive Species}

According to FLEPPC a Category 1 invasive is one that causes ecosystem-level effects, including displacement, hybridization, and any changes to community structure. Category 2 are those that are increasing in terms of abundance but have not been shown to cause ecological changes.

\subsubsection{Category 1 Invasives}

Abrus precatorius (Crab's eye) originates from India and Tropical Asia. It was introduced sometime before 1932 as an ornamental. Most of my inventory records for this invasive are modern and all from Miami-Dade and Monroe counties.

Acacia auriculiformis (Earleaf acacia) originates from Australia, Papua New Guinea, and Indonesia. It was introduced to South Florida sometime before 1932 as an ornamental. Most of my inventory records for this invasive are modern and all from Miami-Dade and Monroe counties.

Albizia julibrissin (Silk tree) originates from Asia. It was introduced to U.S. in 1745 (FLEPPC), and. Introduced and cultivated as an ornamental. My inventory records are modern and only from Collier.

Albizia lebbeck (Rattlepod) originates from Asia and Australia. It was introduced as ornamental in the $1880 \mathrm{~s}$. Most of my inventory records for this invasive are modern.

Bauhinia variegata (Orchid tree) originates in Asia and was introduced to Florida before 1900. All my inventory records are modern and from Miami and Monroe. 
Pueraria montana var. lobatea (Kudzu) originates from Asia, and was introduced to Philadelphia in 1876 as an ornamental. It was first cultivated in Florida in the 1920s for forage (Langeland 2008). Kudzu has been vouchered throughout Florida, however all my records are from Miami-Dade and collected beginning in the 1960s through the 1990s, well after it was declared a weed by USDA in the 1970s.

Senna pendula var. glabrata (Valamuerto) originates from South America. It was likely introduced in the 1930s but cultivated as ornamental in Florida beginning in the 1940s. The only specimens I encountered are from the 1990s.

\subsubsection{Category 2 Invasives}

Dalbergia sissoo (Indian Rosewood) All is seen only in my modern records are modern. Its origin is in Asia. This species is still being sold in nurseries despite its tendency to naturalize. All of my records are modern.

Leucaena leucocephala (White leadtree) is native to Central America. All my records are from Monroe and Miami-Dade. The earliest record is from the 1930s. This species may have possibly been introduced in 1890 s as an agricultural plant, and was touted as a food crop in the latter part of the twentieth century.

Macroptillium lathyroides (Wild bushbean) is native to Tropical Americas. The earliest record I have for this species is from 1952, though it now appears to be widespread in natural areas in Miami-Dade. I have found no other information on its introduction. 
4.7 Species designated as extirpated

Of the six legume species currently listed as extinct or extirpated in the wild, most seem to be Faboideae, and most seem to have last been seen or recorded in the 1960s.

Vachellia choriophylla ( Mimosoideae) is considered extirpated in its native range (Keys). I have one record of it that places it in ENP pine rocklands. IRC records claim the occurrence in Miami-Dade is the result of it being naturalized from cultivation. It was last collected in the 1960s. However, several have been observed growing on the Watson Nature Trail on Big Pine Key.

Chamaecrista deeringiana (Caesalpinioideae) is listed as possibly extirpated in Monroe-Keys. I collected one historical specimen from Monroe from 1912 (Small). According to IRC that is the only time it was recorded in Monroe. There are both historical and modern records for the other counties, and it is still widespread in ENP.

Galactia elliottii (Faboideae) is presumed extirpated in Monroe-Keys, native but not listed for Miami-Dade. Is listed for Monroe and Collier. My inventory resulted in a record from 1973 from Monroe. Assuming it was correctly identified, it could have potentially disappeared after that point.

Desmodium floridanum (Faboideae) is presumed extirpated in Collier County. I have both historical and recent records from Miami-Dade but none from Collier. While there are records of the species in different habitats in Collier I did not find any records of 
them in rocky pinelands for Collier. According to IRC it was last collected in the 1960s in Collier but not necessarily in pine rocklands.

Phaseolus polystachyus var. sinautus ( Faboideae) is assumed extirpated. According to IRC, it was last collected in 1913. My records also do not go past 1913. All records for this species seem to be historical.

Tephrosia angustissima (Faboideae) is now extinct in Miami-Dade. Listed as one of Florida's rare species (FNAI) endemic to pine rockland. According to IRC it was last collected in 1947. I have subsequent collections in 1949 (Buswell) and 1968 (Avery). Assuming these determinations were correct, this means it would have disappeared around the 1960s. 


\section{CONCLUSION}

This inventory provided a 170-year history of floristic exploration of pine rockland Fabaceae. I expected to see an increase in population accompanied by decrease in diversity. However this was not the case as collecting activities were not consistent through time, making it impossible to infer diversity declines with human population numbers alone. The size of pine rocklands in Miami-Dade before major development was estimated at 185000 acres, and by the 1990s, they were estimated at approximately 4,400 acres ( $98 \%$ loss) (Maguire 1995). In 1955 surveys of pine rocklands covered 2,592 acres of BPK, and by 1989 they covered only 1732 acres (Folk et al. 1991). Thus, population induced development as the major determinant of habitat loss for pine rocklands, particularly for Miami-Dade, occurred in less than 100 years.

The key findings of this study demonstrated that the overall frequency of collections fluctuated over time with some species exhibiting patterns which need to be further examined through field surveys. Exotic-invasive plants increased with time especially after the 1960s. This sheds light on the damage caused by early and deliberate introductions of exotic species and reinforces previous knowledge that exotic-invasives seem to be increasingly the most harmful to local biodiversity, after from habitat loss. Other key findings were records of 19 native species not previously listed for the pine rocklands which providing evidence for species presence and the historical distribution of Fabaceae species. The accompanying species list resulting from the inventory also contributes a needed review and status update for the Fabaceae of the region. 
Overall, herbaria are very useful for research as long as one is cognizant of the limitations specifically when it comes to surveys. In this particular study, collection effort exerted the most significant influence on data as compared to other types of biases such as individual collector preference. In addition, researchers should be careful when using online databases and files as some may be incomplete or incorrectly catalogued. I found this to be the case in many instances and was only made aware the problem through the physical inventory. Some institutions are large and have several curators per section which may contribute to undertrained tech staff and volunteers who are unaware of importance of label data to ecological research.

Lastly, conservation of the pine rocklands remains an issue even with surveys indicating roughly a $98 \%$ loss in habitat to date. Miami-Dade County's Environmentally Endangered Lands (EEL) acquisition program has helped conserve $\sim 1,550$ acres of pine rockland habitat but have still been unable procure valuable tracts like Richmond pine rocklands, the biggest fragment outside of ENP. Approximately 88 acres are set to be developed in the next few years, and the Trinity pinelands are also in danger of development. Too many entities currently own pine rocklands and these parcels remain in danger if owners are not willing to sell to EEL or only sell to the highest bidder. Future conservation efforts should focus on buying disturbed lots occurring in areas previously occupied by pine rocklands for restoration. Conservation of individual species is also important as habitat conservation becomes increasingly difficult. There are some ex-situ efforts already underway with the help of local gardens, such as Fairchild Tropical Gardens' Connect to Protect Program. As South Florida has many green spaces as a result of landscaping, the exotic homogenization could be mitigated on a local level by 
promoting landscaping with native plants either by involving home improvement stores or distributing native plants to local neighborhoods. 
Table 1. Summary of the overall collection patterns for native species. The most collected species correlate to the total number of specimens. Species collected 10 decades or more have collection records of $100 \mathrm{yrs}$ or more.

\begin{tabular}{|c|c|c|c|}
\hline Most Collected & Collected $\geq 10$ decades & Decreasing PCF & Increasing PCF \\
\hline $\begin{array}{l}\text { Chamaecrista lineata var. } \\
\text { keyensis }\end{array}$ & Chamaecrista fasciculata & $\begin{array}{l}\text { Dalea carthagenensis } \\
\text { var. floridana } \\
\text { Indigofera miniata }\end{array}$ & $\begin{array}{l}\text { Crotolaria pumila } \\
\text { Desmodium lineatum }\end{array}$ \\
\hline Crotalaria rotundifolia & $\begin{array}{l}\text { Chamaecrista lineata var. } \\
\text { keyensis }\end{array}$ & Neptunia pubescens & Stylosanthes hamata \\
\hline Indigofera miniata & $\begin{array}{l}\text { Chamaecrista nictitans var. } \\
\text { aspera }\end{array}$ & Rhyncosia reniformis & Galactii smallii \\
\hline Rhynchosia reniformis & $\begin{array}{l}\text { Crotalaria pumila } \\
\text { Crotalaria rotundifolia } \\
\text { Neptunia pubescens } \\
\text { Rhynchosia cinera } \\
\text { Rhynchosia minima } \\
\text { Rhynchosia reniformis } \\
\text { Senna mexicana var. } \\
\text { chapmanii }\end{array}$ & $\begin{array}{l}\text { Senna ligustrina } \\
\text { Neptunia pubescens }\end{array}$ & \\
\hline
\end{tabular}


Table 2. Overall Proportional Collection Frequencies(PCFs) for native species, showing $R$. reniformis as the native species with highest PCF.

\begin{tabular}{|c|c|c|c|}
\hline Species & PCF & Species & PCF \\
\hline Acaciella angustissima & 0.27 & Guilandina bonduc & 0.45 \\
\hline Aeschynomene pratensis & 0.18 & Indigofera caroliniana & 0.27 \\
\hline Aeschynomene viscidula & 1.25 & Indigofera miniata & 5.00 \\
\hline Amorpha fruticosa & 0.18 & Lysiloma latisiliquum & 0.71 \\
\hline Amorpha herbacea var. crenulata & 0.80 & Mimosa quadrivalvis var. angustata & 0.71 \\
\hline Canavalia rosea & 0.09 & Neptunia pubescens & 3.57 \\
\hline Centrosema virginianum & 2.05 & Phaseolus polystachyus var. sinautus* & 0.27 \\
\hline Chamaecrista deeringiana & 1.96 & Piscidia piscipula & 0.54 \\
\hline Chamaecrista fasciculata & 2.68 & Pithecellobium angus-cacti & 0.09 \\
\hline Chamaecrista lineata var. keyensis & 5.45 & Pithecellobium bahamense & 0.09 \\
\hline Chamaecrista nictitans & 0.54 & Pithecellobium keyense & 2.05 \\
\hline Chamaecrista nictitans var. aspera & 3.57 & Rhynchosia cinera & 2.50 \\
\hline Clitoria mariana & 0.27 & Rhynchosia michauxii & 1.25 \\
\hline Crotalaria pumila & 4.38 & Rhynchosia minima & 1.96 \\
\hline Crotalaria rotundifolia & 5.45 & Rhynchosia parvifolia & 2.41 \\
\hline Dalea carnea & 3.30 & Rhynchosia reniformis & 7.41 \\
\hline Dalea carthagenensis var. floridana & 1.07 & Senna ligustrina & 2.41 \\
\hline Dalea feayi & 0.18 & Senna mexicana var. chapmanii & 3.39 \\
\hline Denisophytum pauciflorum & 3.21 & Senna obtusifolia & 0.09 \\
\hline Desmanthus virgatus & 0.09 & Sesbania herbaceae & 0.09 \\
\hline Desmodium ciliare & 0.27 & Sesbania vesicaria & 0.27 \\
\hline Desmodium floridanum & 0.36 & Sophora tomentosa & 0.71 \\
\hline Desmodium incanum & 0.80 & Stylosanthes biflora & 0.09 \\
\hline Desmodium lineatum & 0.63 & Stylosanthes calcicola & 2.14 \\
\hline Desmodium marilandicum & 1.07 & Stylosanthes hamata & 0.63 \\
\hline Desmodium obtusum & 0.27 & Stylosanthes ligustrina & 0.09 \\
\hline Desmodium strictum & 0.18 & Tephrosia angustissima* & 1.70 \\
\hline Erythrina herbacea & 0.09 & Tephrosia florida & 0.63 \\
\hline Galactia elliottii & 0.09 & Tephrosia spicata & 0.71 \\
\hline Galactia floridana & 1.07 & Vachellia choriophylla & 0.09 \\
\hline Galactia parvifolia & 0.45 & Vachellia farnesiana var. farnesiana & 2.86 \\
\hline Galactia pinetorum & 3.21 & Vachellia farnesiana var. pinetorum & 1.52 \\
\hline Galactia regularis & 2.68 & Vicia acutifolia & 0.09 \\
\hline Galactia smallii & 1.52 & Vigna luteola & 0.36 \\
\hline Galactia striata & 0.63 & Zornia bracteata & 1.16 \\
\hline Galactia volubilis & 1.43 & & \\
\hline
\end{tabular}


Table 3. Post Inventory Species List Summary

\begin{tabular}{|c|c|}
\hline Total Species & 122 \\
\hline Genera & 56 \\
\hline Native Species & 71 \\
\hline Exotic Species & 41 \\
\hline Invasive Species & 10 \\
\hline Extinct Taxa & 5 \\
\hline IUCN Listed Taxa & 8 \\
\hline ESA Listed Taxa & 5 \\
\hline Florida Listed Taxa & 15 \\
\hline
\end{tabular}


Table 4. Proportional Collection Frequency for all native species for the decades of 1830-2010

\begin{tabular}{|c|c|c|c|c|c|c|c|c|c|c|c|c|c|c|c|c|c|c|c|}
\hline Species & 1830 & 1840 & 1850 & 1860 & 1870 & 1880 & 1890 & 1900 & 1910 & 1920 & 1930 & 1940 & 1950 & 1960 & 1970 & 1980 & 1990 & 2000 & 2010 \\
\hline $\begin{array}{l}\text { Acaciella } \\
\text { angustissima }\end{array}$ & 0.0 & 0.0 & 0.0 & 0.0 & 0.0 & 0.00 & 0.00 & 2.63 & 0.00 & 0.00 & 0.00 & 0.00 & 0.00 & 0.00 & 0.00 & 0.00 & 0.00 & 0.00 & 0.0 \\
\hline $\begin{array}{l}\text { Aeschynomene } \\
\text { pratensis }\end{array}$ & 0.0 & 0.0 & 0.0 & 0.0 & 0.0 & 0.00 & 0.00 & 0.88 & 0.00 & 0.00 & 0.00 & 0.00 & 0.00 & 0.67 & 0.00 & 0.00 & 0.00 & 0.00 & 0.0 \\
\hline $\begin{array}{l}\text { Aeschynomene } \\
\text { viscidula }\end{array}$ & 0.0 & 0.00 & 0.0 & 0.0 & 0.0 & 0.00 & 0.00 & 0.00 & 0.40 & 0.00 & 0.00 & 0.00 & 0.00 & 0.00 & 2.29 & 1.43 & 3.98 & 3.9 & 0.0 \\
\hline $\begin{array}{l}\text { Amorpha } \\
\text { fruticosa }\end{array}$ & 0.0 & 0.0 & 0.0 & 0.0 & 0.0 & 0.00 & 0.00 & 0.88 & 0.00 & 0.00 & 0.00 & 0.00 & 0.00 & 0.0 & 0.7 & 0.0 & 0.0 & 0.0 & 0.0 \\
\hline $\begin{array}{l}\text { Amorpha } \\
\text { herbacea var. } \\
\text { crenulata }\end{array}$ & 0.0 & 0.0 & 0.0 & 0.0 & 0.0 & 0.00 & 0.00 & 0.88 & 0.81 & 4.76 & 3.23 & 3.23 & 0.00 & 0.00 & 1.53 & 0.00 & 0.5 & 1.9 & 0.0 \\
\hline $\begin{array}{l}\text { Canavalia } \\
\text { rosea }\end{array}$ & 0.0 & 0.0 & 0.0 & 0.0 & 0.0 & 0.00 & 0.00 & 0.00 & 0.00 & 0.00 & 0.00 & 100 & 0.00 & 0.00 & 0.00 & 0.00 & 0.0 & 0.0 & 0.0 \\
\hline $\begin{array}{l}\text { Centrosema } \\
\text { virginianum }\end{array}$ & 0.0 & 0.0 & 0.0 & 0.0 & 0.0 & 0.00 & 0.00 & 0.00 & 0.40 & 4.76 & 0.00 & 0.00 & 2.90 & 3.33 & 2.29 & 4.29 & 3.98 & 1.9 & 0.0 \\
\hline $\begin{array}{l}\text { Chamaecrista } \\
\text { deeringiana } \\
\text { (*keys) }\end{array}$ & 0.0 & 0.0 & 0.0 & 0.0 & 0.0 & 0.00 & 0.00 & 0.00 & 2.42 & 0.00 & 0.00 & 0.00 & 0.00 & 0.00 & 7.63 & 0.00 & 3.41 & 0.0 & 0.0 \\
\hline $\begin{array}{l}\text { Chamaecrista } \\
\text { fasciculata }\end{array}$ & 0.0 & 0.0 & 0.0 & 0.0 & 0.0 & 0.00 & 33.3 & 2.63 & 0.81 & 0.00 & 9.68 & 9.68 & 1.45 & 6.67 & 0.76 & 7.14 & 1.14 & 1.9 & 0.0 \\
\hline $\begin{array}{l}\text { Chamaecrista } \\
\text { lineata var. } \\
\text { keyensis }\end{array}$ & 0.0 & 0.0 & 0.0 & 0.0 & 0.0 & 0.00 & 9.52 & 0.00 & 6.05 & 9.52 & 6.45 & 6.45 & 4.35 & 3.33 & 8.40 & 1.43 & 4.55 & 11.7 & 0.0 \\
\hline $\begin{array}{l}\text { Chamaecrista } \\
\text { nictitans var. } \\
\text { aspera }\end{array}$ & 33.3 & 33.3 & 0.0 & 0.0 & 0.00 & 0.00 & 0.00 & 3.51 & 3.63 & 4.76 & 12.9 & 12.9 & 8.70 & 2.00 & 2.29 & 4.29 & 4.55 & 1.9 & 0.0 \\
\hline $\begin{array}{l}\text { Clitoria } \\
\text { mariana }\end{array}$ & 0.0 & 0.0 & 0.0 & 0.0 & 0.00 & 0.00 & 0.00 & 0.00 & 1.21 & 0.00 & 0.00 & 0.00 & 0.00 & 0.00 & 0.00 & 0.00 & 0.00 & 0.0 & 0.0 \\
\hline $\begin{array}{l}\text { Crotalaria } \\
\text { pumila }\end{array}$ & 0.0 & 0.0 & 0.0 & 0.0 & 0.00 & 0.00 & 0.00 & 5.26 & 3.23 & 14.2 & 0.00 & 0.00 & 4.35 & 5.33 & 5.34 & 12.86 & 1.70 & 1.9 & 25.0 \\
\hline $\begin{array}{l}\text { Crotalaria } \\
\text { rotundifolia }\end{array}$ & 0.0 & 0.0 & 0.0 & 0.00 & 0.00 & 0.00 & 0.00 & 3.51 & 10.4 & 9.52 & 0.00 & 0.00 & 4.35 & 4.67 & 2.29 & 5.71 & 5.11 & 3.92 & 0.0 \\
\hline Dalea carnea & 0.00 & 0.00 & 0.00 & 0.00 & 0.00 & 0.00 & 4.76 & 2.63 & 2.82 & 19.0 & 3.23 & 3.23 & 0.00 & 3.33 & 1.53 & 2.86 & 6.25 & 3.9 & 0.0 \\
\hline
\end{tabular}




\begin{tabular}{|c|c|c|c|c|c|c|c|c|c|c|c|c|c|c|c|c|c|c|c|}
\hline $\begin{array}{l}\text { Dalea } \\
\text { carthagenensis } \\
\text { var. floridana }\end{array}$ & 0.00 & 0.00 & 0.00 & 0.00 & 0.00 & 12.5 & 0.00 & 2.63 & 0.00 & 0.00 & 0.00 & 0.00 & 0.00 & 0.00 & 1.53 & 0.00 & 1.70 & 0.0 & 0.0 \\
\hline Dalea feayi & 0.00 & 0.00 & 0.00 & 0.00 & 0.00 & 0.00 & 4.76 & 0.00 & 0.00 & 0.00 & 0.00 & 0.00 & 0.00 & 0.00 & 0.76 & 1.43 & 0.00 & 0.00 & 0.00 \\
\hline $\begin{array}{l}\text { Denisophytum } \\
\text { pauciflorum }\end{array}$ & 0.00 & 0.00 & 0.00 & 0.00 & 0.00 & 8.33 & 0.00 & 0.00 & 3.23 & 0.00 & 0.00 & 0.00 & 14.49 & 3.33 & 3.82 & 1.43 & 0.00 & 3.92 & 0.00 \\
\hline $\begin{array}{l}\text { Desmanthus } \\
\text { virgatus }\end{array}$ & 0.00 & 0.00 & 0.00 & 0.00 & 0.00 & 4.17 & 0.00 & 0.00 & 0.00 & 0.00 & 0.00 & 0.00 & 1.45 & 0.67 & 0.00 & 0.00 & 0.57 & 0.00 & 0.00 \\
\hline $\begin{array}{l}\text { Desmodium } \\
\text { ciliare }\end{array}$ & 0.00 & 0.00 & 0.00 & 0.00 & 0.00 & 0.00 & 0.00 & 0.00 & 0.00 & 0.00 & 0.00 & 0.00 & 0.00 & 0.67 & 0.00 & 0.00 & 1.14 & 0.00 & 0.00 \\
\hline $\begin{array}{l}\text { Desmodium } \\
\text { floridanum }\end{array}$ & 0.00 & 0.00 & 0.00 & 0.00 & 0.00 & 0.00 & 0.00 & 0.00 & 0.40 & 0.00 & 0.00 & 0.00 & 0.00 & 0.00 & 0.00 & 0.00 & 1.14 & 1.96 & 0.00 \\
\hline $\begin{array}{l}\text { Desmodium } \\
\text { incanum }\end{array}$ & 0.00 & 0.00 & 0.00 & 0.00 & 0.00 & 4.17 & 0.00 & 0.00 & 0.40 & 0.00 & 3.23 & 3.23 & 0.00 & 1.33 & 2.29 & 0.00 & 0.57 & 0.00 & 0.00 \\
\hline $\begin{array}{l}\text { Desmodium } \\
\text { lineatum( }\end{array}$ & 0.00 & 0.00 & 0.00 & 0.00 & 0.00 & 0.00 & 0.00 & 0.00 & 0.81 & 0.00 & 0.00 & 0.00 & 0.00 & 0.00 & 0.00 & 0.00 & 1.14 & 3.92 & 25.00 \\
\hline $\begin{array}{l}\text { Desmodium } \\
\text { marilandicum }\end{array}$ & 0.00 & 0.00 & 0.00 & 0.00 & 0.00 & 0.00 & 0.00 & 0.00 & 0.00 & 0.00 & 0.00 & 0.00 & 0.00 & 2.00 & 0.76 & 1.43 & 3.41 & 0.00 & 0.00 \\
\hline $\begin{array}{l}\text { Desmodium } \\
\text { obtusum }\end{array}$ & 0.00 & 0.00 & 0.00 & 0.00 & 0.00 & 0.00 & 0.00 & 0.00 & 0.40 & 0.00 & 0.00 & 0.00 & 0.00 & 0.00 & 0.00 & 0.00 & 0.00 & 0.00 & 0.00 \\
\hline $\begin{array}{l}\text { Desmodium } \\
\text { strictum }\end{array}$ & 0.00 & 0.00 & 0.00 & 0.00 & 0.00 & 0.00 & 0.00 & 0.00 & 0.00 & 0.00 & 0.00 & 0.00 & 0.00 & 0.00 & 1.53 & 0.00 & 0.00 & 0.00 & 0.00 \\
\hline $\begin{array}{l}\text { Erythrina } \\
\text { herbacea }\end{array}$ & 0.00 & 0.00 & 0.00 & 0.00 & 0.00 & 0.00 & 0.00 & 0.00 & 0.00 & 0.00 & 0.00 & 0.00 & 0.00 & 0.67 & 0.00 & 0.00 & 0.00 & 0.00 & 0.00 \\
\hline $\begin{array}{l}\text { Galactia } \\
\text { elliottii }\end{array}$ & 0.00 & 0.00 & 0.00 & 0.00 & 0.00 & 0.00 & 0.00 & 0.00 & 0.00 & 0.00 & 0.00 & 0.00 & 0.00 & 0.00 & 0.76 & 0.00 & 0.00 & 0.00 & 0.00 \\
\hline $\begin{array}{l}\text { Galactia } \\
\text { floridana }\end{array}$ & 0.00 & 0.00 & 0.00 & 0.00 & 0.00 & 0.00 & 0.00 & 0.00 & 0.40 & 0.00 & 0.00 & 0.00 & 0.00 & 0.00 & 3.82 & 2.86 & 0.57 & 1.96 & 0.00 \\
\hline $\begin{array}{l}\text { Galactia } \\
\text { grisebachii }\end{array}$ & 0.00 & 0.00 & 0.00 & 0.00 & 0.00 & 0.00 & 0.00 & 0.00 & 0.00 & 0.00 & 0.00 & 0.00 & 0.00 & 1.33 & 0.76 & 2.86 & 0.00 & 0.00 & 0.00 \\
\hline $\begin{array}{l}\text { Galactia } \\
\text { pinetorum }\end{array}$ & 0.00 & 0.00 & 0.00 & 0.00 & 0.00 & 0.00 & 0.00 & 6.14 & 2.02 & 4.76 & 0.00 & 0.00 & 0.00 & 4.00 & 3.05 & 8.57 & 2.27 & 3.92 & 0.00 \\
\hline $\begin{array}{l}\text { Galactia } \\
\text { regularis }\end{array}$ & 0.00 & 0.00 & 0.00 & 0.00 & 0.00 & 0.00 & 0.00 & 2.63 & 4.03 & 0.00 & 0.00 & 0.00 & 0.00 & 2.00 & 2.29 & 2.86 & 5.68 & 1.96 & 0.00 \\
\hline $\begin{array}{l}\text { Galactia } \\
\text { smallii }\end{array}$ & 0.00 & 0.00 & 0.00 & 0.00 & 0.00 & 0.00 & 0.00 & 2.63 & 0.81 & 0.00 & 0.00 & 0.00 & 0.00 & 1.33 & 2.29 & 1.43 & 1.70 & 0.00 & 25.00 \\
\hline $\begin{array}{l}\text { Galactia } \\
\text { striata }\end{array}$ & 0.00 & 0.00 & 0.00 & 0.00 & 0.00 & 0.00 & 0.00 & 1.75 & 0.00 & 0.00 & 0.00 & 0.00 & 0.00 & 0.00 & 0.00 & 4.29 & 0.00 & 1.96 & 0.00 \\
\hline $\begin{array}{l}\text { Galactia } \\
\text { volubilis }\end{array}$ & 0.00 & 0.00 & 0.00 & 0.00 & 0.00 & 0.00 & 0.00 & 3.51 & 2.82 & 0.00 & 0.00 & 0.00 & 0.00 & 2.00 & 1.53 & 0.00 & 0.00 & 0.00 & 0.00 \\
\hline $\begin{array}{l}\text { Guilandina } \\
\text { bonduc }\end{array}$ & 0.00 & $\begin{array}{c}33.3 \\
3\end{array}$ & 0.00 & 0.00 & 100.0 & 8.33 & 0.00 & 0.88 & 0.00 & 0.00 & 0.00 & 0.00 & 0.00 & 0.00 & 0.00 & 0.00 & 0.00 & 0.00 & 0.00 \\
\hline $\begin{array}{l}\text { Indigofera } \\
\text { caroliniana }\end{array}$ & 0.00 & 0.00 & 0.00 & 0.00 & 0.00 & 0.00 & 0.00 & 0.00 & 0.00 & 0.00 & 0.00 & 0.00 & 0.00 & 2.00 & 0.00 & 0.00 & 0.00 & 0.00 & 0.00 \\
\hline $\begin{array}{l}\text { Indigofera } \\
\text { miniata }\end{array}$ & 0.00 & 0.00 & 0.00 & 0.00 & 0.00 & 0.00 & 0.00 & 7.89 & 11.69 & 0.00 & 0.00 & 0.00 & 2.90 & 6.00 & 0.00 & 1.43 & 2.84 & 1.96 & 0.00 \\
\hline
\end{tabular}




\begin{tabular}{|c|c|c|c|c|c|c|c|c|c|c|c|c|c|c|c|c|c|c|c|}
\hline $\begin{array}{l}\text { Lysiloma } \\
\text { latisiliquum }\end{array}$ & 0.00 & 0.00 & 0.00 & 0.00 & 0.00 & 0.00 & 0.00 & 0.00 & 0.00 & 0.00 & 0.00 & 0.00 & 0.00 & 3.33 & 0.00 & 0.00 & 1.70 & 0.00 & 0.00 \\
\hline $\begin{array}{l}\text { Mimosa } \\
\text { quadrivalvis } \\
\text { var. angustata }\end{array}$ & 0.00 & 0.00 & 0.00 & 0.00 & 0.00 & 0.00 & 9.52 & 0.00 & 0.00 & 0.00 & 0.00 & 0.00 & 0.00 & 4.00 & 1.53 & 0.00 & 0.00 & 0.00 & 0.00 \\
\hline $\begin{array}{l}\text { Neptunia } \\
\text { pubescens }\end{array}$ & 33.33 & 0.00 & 0.00 & 0.00 & 0.00 & 16.67 & 0.00 & 6.14 & 2.42 & 4.76 & 6.45 & 6.45 & 4.35 & 2.67 & 0.76 & 0.00 & 4.55 & 1.96 & 0.00 \\
\hline $\begin{array}{l}\text { Phaseolus } \\
\text { polystachyus } \\
\text { var. sinautus* }\end{array}$ & 0.00 & 0.00 & 0.00 & 0.00 & 0.00 & 0.00 & 0.00 & 0.00 & 1.21 & 0.00 & 0.00 & 0.00 & 0.00 & 0.00 & 0.00 & 0.00 & 0.00 & 0.00 & 0.00 \\
\hline $\begin{array}{l}\text { Piscidia } \\
\text { piscipula }\end{array}$ & 0.00 & 0.00 & 0.00 & 0.00 & 0.00 & 0.00 & 0.00 & 0.00 & 0.40 & 0.00 & 0.00 & 0.00 & 1.45 & 0.67 & 2.29 & 0.00 & 0.00 & 0.00 & 0.00 \\
\hline $\begin{array}{l}\text { Pithecellobium } \\
\text { angus-cacti }\end{array}$ & 0.00 & 0.00 & 0.00 & 0.00 & 0.00 & 0.00 & 0.00 & 0.00 & 0.00 & 0.00 & 0.00 & 0.00 & 1.45 & 0.00 & 0.00 & 0.00 & 0.00 & 0.00 & 0.00 \\
\hline $\begin{array}{l}\text { Pithecellobium } \\
\text { bahamense }\end{array}$ & 0.00 & 0.00 & 0.00 & 0.00 & 0.00 & 0.00 & 0.00 & 0.00 & 0.00 & 0.00 & 0.00 & 0.00 & 0.00 & 0.00 & 0.00 & 0.00 & 0.00 & 1.96 & 0.00 \\
\hline $\begin{array}{l}\text { Pithecellobium } \\
\text { keyense }\end{array}$ & 0.00 & 0.00 & 0.00 & 0.00 & 0.00 & 0.00 & 0.00 & 0.00 & 0.40 & 0.00 & 16.13 & 16.13 & 7.25 & 1.33 & 3.05 & 1.43 & 2.27 & 0.00 & 0.00 \\
\hline $\begin{array}{l}\text { Rhynchosia } \\
\text { cinera }\end{array}$ & 0.00 & 0.00 & 0.00 & 0.00 & 0.00 & 0.00 & 0.00 & 1.75 & 1.21 & 0.00 & 3.23 & 3.23 & 7.25 & 1.33 & 3.82 & 2.86 & 1.70 & 3.92 & 0.00 \\
\hline $\begin{array}{l}\text { Rhynchosia } \\
\text { michauxii }\end{array}$ & 0.00 & 0.00 & 0.00 & 0.00 & 0.00 & 0.00 & 4.76 & 0.88 & 1.61 & 4.76 & 3.23 & 3.23 & 0.00 & 0.00 & 0.00 & 0.00 & 2.27 & 0.00 & 0.00 \\
\hline $\begin{array}{l}\text { Rhynchosia } \\
\text { minima }\end{array}$ & 0.00 & 0.00 & 0.00 & 0.00 & 0.00 & 16.67 & 0.00 & 2.63 & 0.40 & 0.00 & 3.23 & 3.23 & 1.45 & 2.67 & 1.53 & 2.86 & 0.57 & 1.96 & 0.00 \\
\hline $\begin{array}{l}\text { Rhynchosia } \\
\text { parvifolia }\end{array}$ & 0.00 & 0.00 & 0.00 & 0.00 & 0.00 & 0.00 & 0.00 & 2.63 & 2.02 & 0.00 & 3.23 & 3.23 & 5.80 & 2.67 & 2.29 & 1.43 & 3.41 & 0.00 & 0.00 \\
\hline $\begin{array}{l}\text { Rhynchosia } \\
\text { reniformis }\end{array}$ & 0.00 & 0.00 & 0.00 & 0.00 & 0.00 & 0.00 & 23.81 & 14.04 & 13.71 & 0.00 & 3.23 & 3.23 & 1.45 & 2.00 & 5.34 & 4.29 & 2.84 & 5.88 & 0.00 \\
\hline $\begin{array}{l}\text { Senna } \\
\text { ligustrina }\end{array}$ & 0.00 & $\begin{array}{c}33.3 \\
3\end{array}$ & 0.00 & 0.00 & 0.00 & 20.83 & 0.00 & 0.00 & 0.40 & 4.76 & 0.00 & 0.00 & 4.35 & 3.33 & 2.29 & 0.00 & 1.70 & 0.00 & 0.00 \\
\hline $\begin{array}{l}\text { Senna } \\
\text { mexicana var. } \\
\text { chapmanii }\end{array}$ & 0.00 & 0.00 & 0.00 & 0.00 & 0.00 & 4.17 & 0.00 & 0.00 & 0.40 & 4.76 & 3.23 & 3.23 & 5.80 & 4.67 & 5.34 & 2.86 & 4.55 & 9.80 & 0.00 \\
\hline $\begin{array}{l}\text { Senna } \\
\text { obtusifolia }\end{array}$ & 0.00 & 0.00 & 0.00 & 0.00 & 0.00 & 0.00 & 0.00 & 0.00 & 0.00 & 0.00 & 0.00 & 0.00 & 0.00 & 0.00 & 0.00 & 0.00 & 0.57 & 0.00 & 0.00 \\
\hline $\begin{array}{l}\text { Sesbania } \\
\text { herbaceae }\end{array}$ & 0.00 & 0.00 & 0.00 & 0.00 & 0.00 & 0.00 & 0.00 & 0.00 & 0.00 & 0.00 & 0.00 & 0.00 & 0.00 & 0.67 & 0.00 & 0.00 & 0.00 & 0.00 & 0.00 \\
\hline $\begin{array}{l}\text { Sesbania } \\
\text { vesicaria }\end{array}$ & 0.00 & 0.00 & 0.00 & 0.00 & 0.00 & 0.00 & 0.00 & 1.75 & 0.40 & 0.00 & 0.00 & 0.00 & 0.00 & 0.00 & 0.00 & 0.00 & 0.00 & 0.00 & 0.00 \\
\hline $\begin{array}{l}\text { Sophora } \\
\text { tomentosa }\end{array}$ & 0.00 & 0.00 & 0.00 & 0.00 & 0.00 & 0.00 & 0.00 & 0.00 & 0.00 & 0.00 & 0.00 & 0.00 & 2.90 & 0.67 & 0.76 & 0.00 & 1.70 & 1.96 & 0.00 \\
\hline $\begin{array}{l}\text { Stylosanthes } \\
\text { biflora }\end{array}$ & 0.00 & 0.00 & 0.00 & 0.00 & 0.00 & 0.00 & 0.00 & 0.00 & 0.00 & 0.00 & 0.00 & 0.00 & 0.00 & 0.00 & 0.00 & 0.00 & 0.57 & 0.00 & 0.00 \\
\hline $\begin{array}{l}\text { Stylosanthes } \\
\text { calcicola }\end{array}$ & 0.00 & 0.00 & 0.00 & 0.00 & 0.00 & 0.00 & 0.00 & 0.00 & 2.82 & 0.00 & 0.00 & 0.00 & 4.35 & 3.33 & 0.00 & 0.00 & 5.11 & 0.00 & 0.00 \\
\hline
\end{tabular}




\begin{tabular}{|c|c|c|c|c|c|c|c|c|c|c|c|c|c|c|c|c|c|c|c|}
\hline $\begin{array}{l}\text { Stylosanthes } \\
\text { hamata }\end{array}$ & 0.00 & 0.00 & 0.00 & 0.00 & 0.00 & 0.00 & 0.00 & 0.00 & 0.00 & 0.00 & 0.00 & 0.00 & 0.00 & 0.00 & 1.53 & 0.00 & 1.70 & 3.92 & 0.00 \\
\hline $\begin{array}{l}\text { Stylosanthes } \\
\text { ligustrina }\end{array}$ & 0.00 & 0.00 & 0.00 & 0.00 & 0.00 & 0.00 & 0.00 & 0.00 & 0.40 & 0.00 & 0.00 & 0.00 & 0.00 & 0.00 & 0.00 & 0.00 & 0.00 & 0.00 & 0.00 \\
\hline $\begin{array}{l}\text { Tephrosia } \\
\text { angustissima }\end{array}$ & 0.00 & 0.00 & 0.00 & 0.00 & 0.00 & 0.00 & 0.00 & 8.77 & 1.61 & 0.00 & 0.00 & 0.00 & 0.00 & 0.67 & 0.00 & 0.00 & 0.00 & 0.00 & 0.00 \\
\hline $\begin{array}{l}\text { Tephrosia } \\
\text { florida }\end{array}$ & 0.00 & 0.00 & 0.00 & 0.00 & 0.00 & 0.00 & 0.00 & 2.63 & 5.24 & 0.00 & 9.68 & 9.68 & 0.00 & 4.00 & 2.29 & 5.71 & 2.27 & 7.84 & 0.00 \\
\hline $\begin{array}{l}\text { Tephrosia } \\
\text { spicata }\end{array}$ & 0.00 & 0.00 & 0.00 & 0.00 & 0.00 & 0.00 & 0.00 & 2.63 & 0.81 & 0.00 & 0.00 & 0.00 & 0.00 & 0.00 & 0.76 & 0.00 & 1.14 & 0.00 & 0.00 \\
\hline $\begin{array}{l}\text { Vachellia } \\
\text { choriophylla }\end{array}$ & 0.00 & 0.00 & 0.00 & 0.00 & 0.00 & 0.00 & 4.76 & 0.00 & 0.00 & 0.00 & 0.00 & 0.00 & 0.00 & 0.00 & 0.00 & 0.00 & 0.57 & 0.00 & 0.00 \\
\hline $\begin{array}{l}\text { Vachellia } \\
\text { farnesiana var. } \\
\text { farnesiana }\end{array}$ & 33.33 & 0.00 & 0.00 & 0.00 & 0.00 & 4.17 & 4.76 & 2.63 & 0.00 & 0.00 & 9.68 & 9.68 & 4.35 & 2.67 & 3.05 & 7.14 & 2.27 & 1.96 & 25.00 \\
\hline $\begin{array}{l}\text { Vachellia } \\
\text { farnesiana var. } \\
\text { pinetorum }\end{array}$ & 0.00 & 0.00 & 0.00 & 0.00 & 0.00 & 0.00 & 0.00 & 1.75 & 0.00 & 4.76 & 0.00 & 0.00 & 2.90 & 2.67 & 1.53 & 2.86 & 0.57 & 1.96 & 0.00 \\
\hline Vicia acutifolia & 0.00 & 0.00 & 0.00 & 0.00 & 0.00 & 0.00 & 0.00 & 0.00 & 0.00 & 0.00 & 0.00 & 0.00 & 0.00 & 0.00 & 0.00 & 0.00 & 0.00 & 1.96 & 0.00 \\
\hline Vigna luteola & 0.00 & 0.00 & 0.00 & 0.00 & 0.00 & 0.00 & 0.00 & 0.88 & 0.40 & 4.76 & 0.00 & 0.00 & 0.00 & 0.00 & 0.76 & 0.00 & 0.00 & 0.00 & 0.00 \\
\hline $\begin{array}{l}\text { Zornia } \\
\text { bracteata }\end{array}$ & 0.00 & 0.00 & 0.00 & 0.00 & 0.00 & 0.00 & 0.00 & 0.00 & 4.84 & 0.00 & 0.00 & 0.00 & 0.00 & 0.00 & 0.76 & 0.00 & 0.00 & 0.00 & 0.00 \\
\hline
\end{tabular}


$\underbrace{40}_{\text {工I }}$

20

10

0 1830

Figure 1. Estimated collections richness for all species for the decades of 1830-2010. 


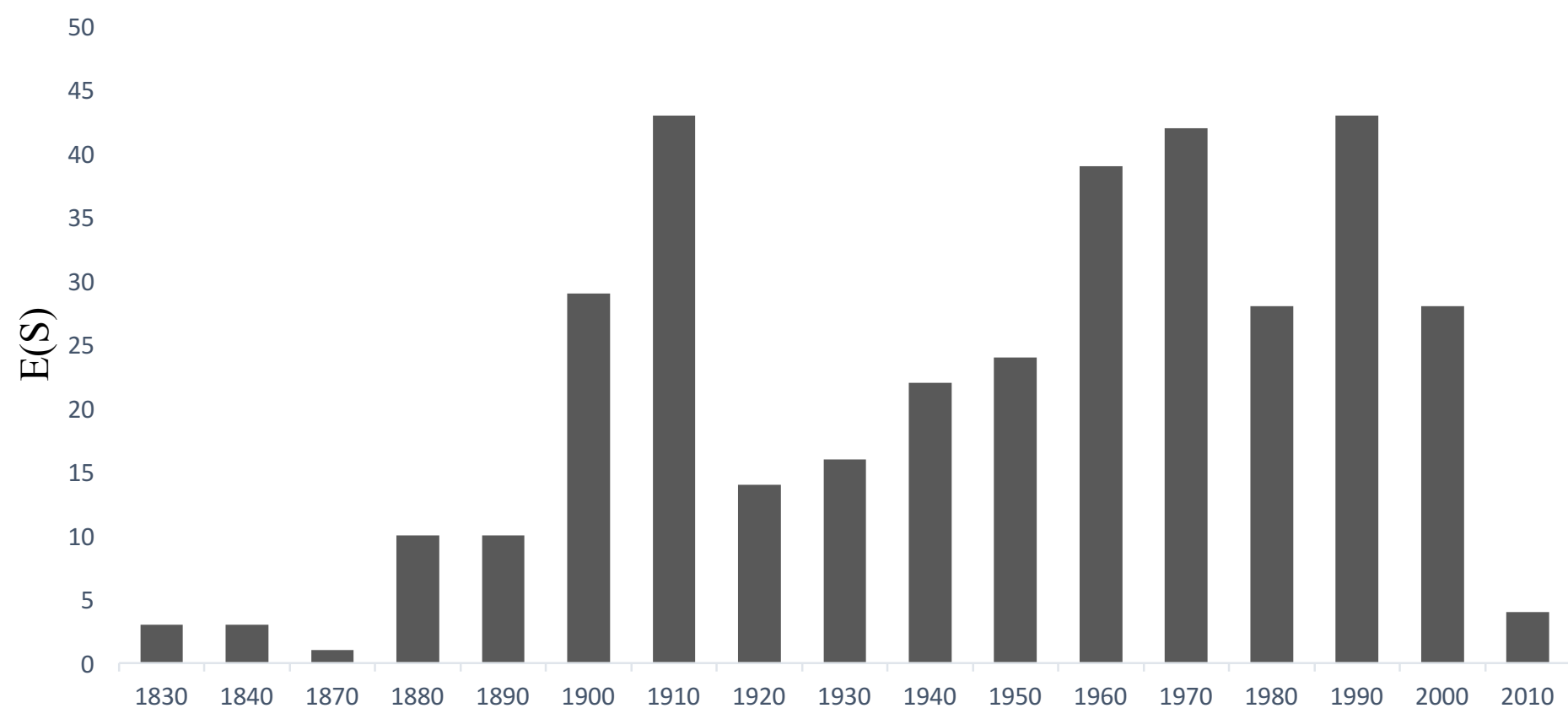

Figure 2. Estimated collections richness for native species for the decades of 1830-2010. 


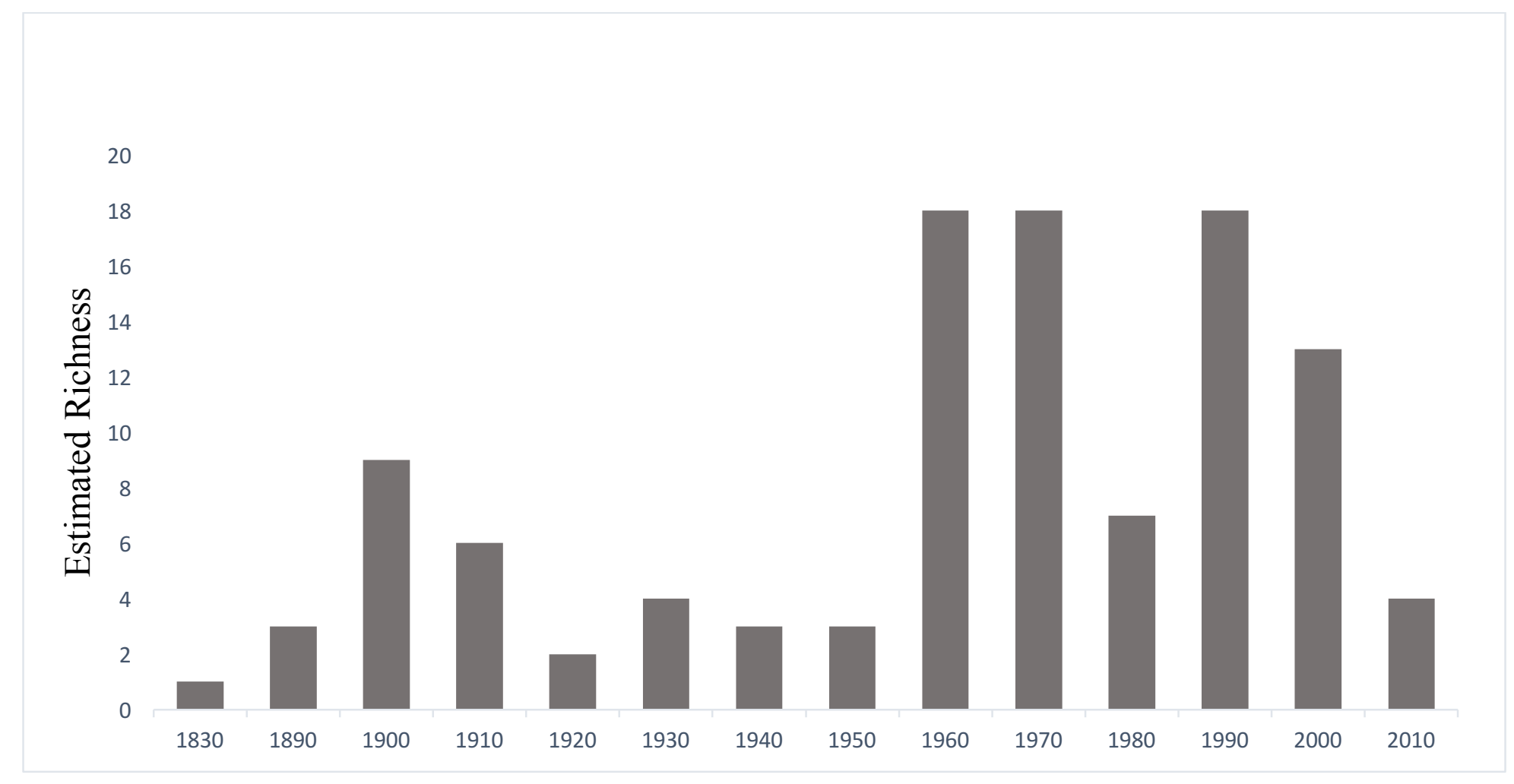

Figure 3. Estimated collections richness for non-native species for the decades of 1830-2010. 


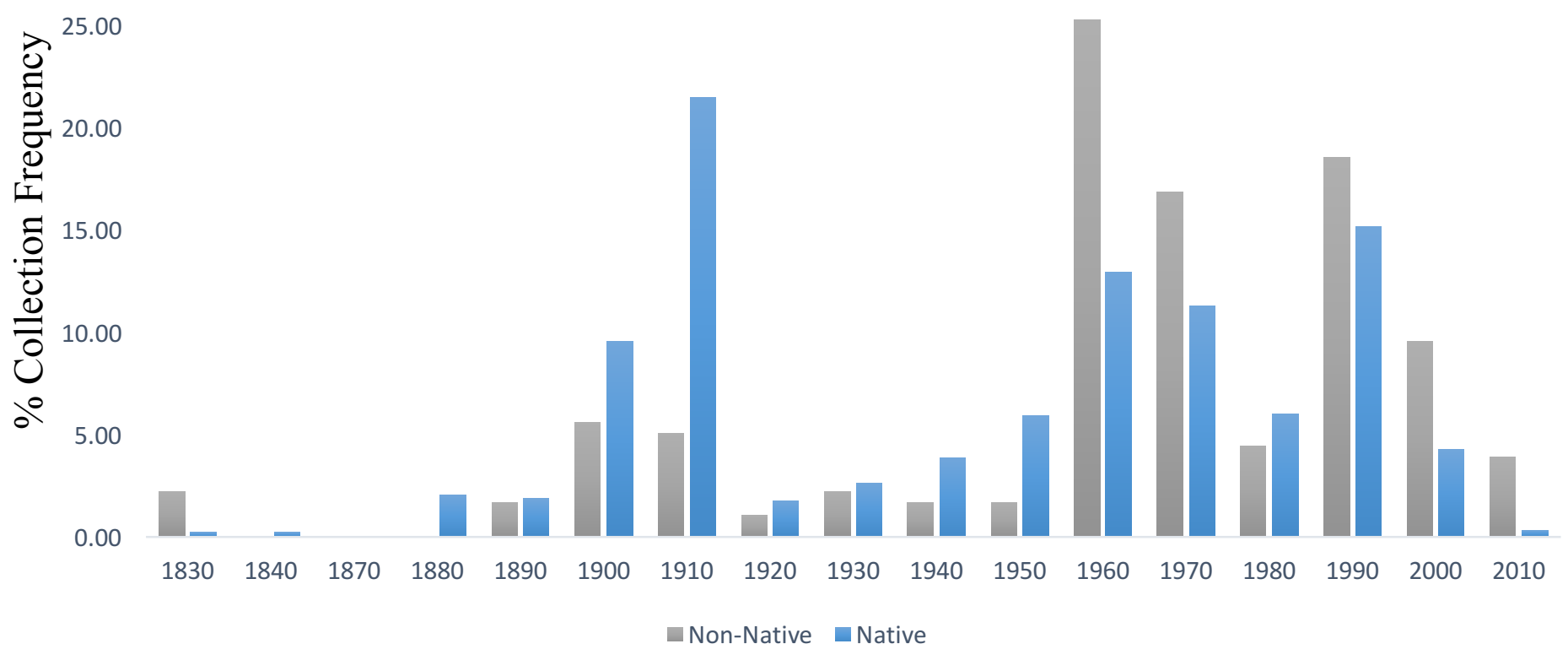

Figure 4. Proportional Collection Frequency (PFC) for native and non-native species for the decades of 1830-2010. 


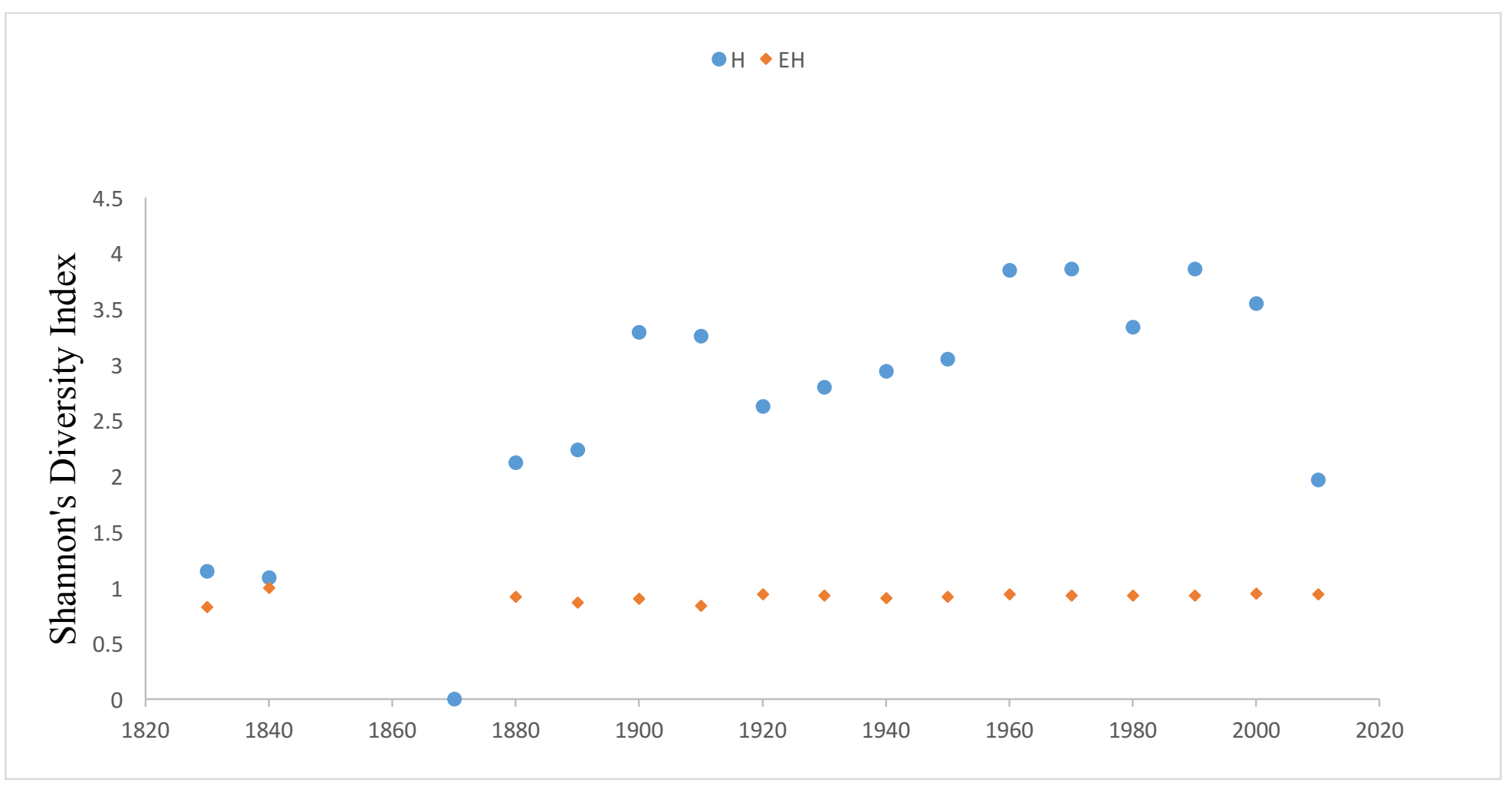

Figure 5. Shannon's diversity index(H) and Shannon's equitability index for the decades of 1830-2010. 


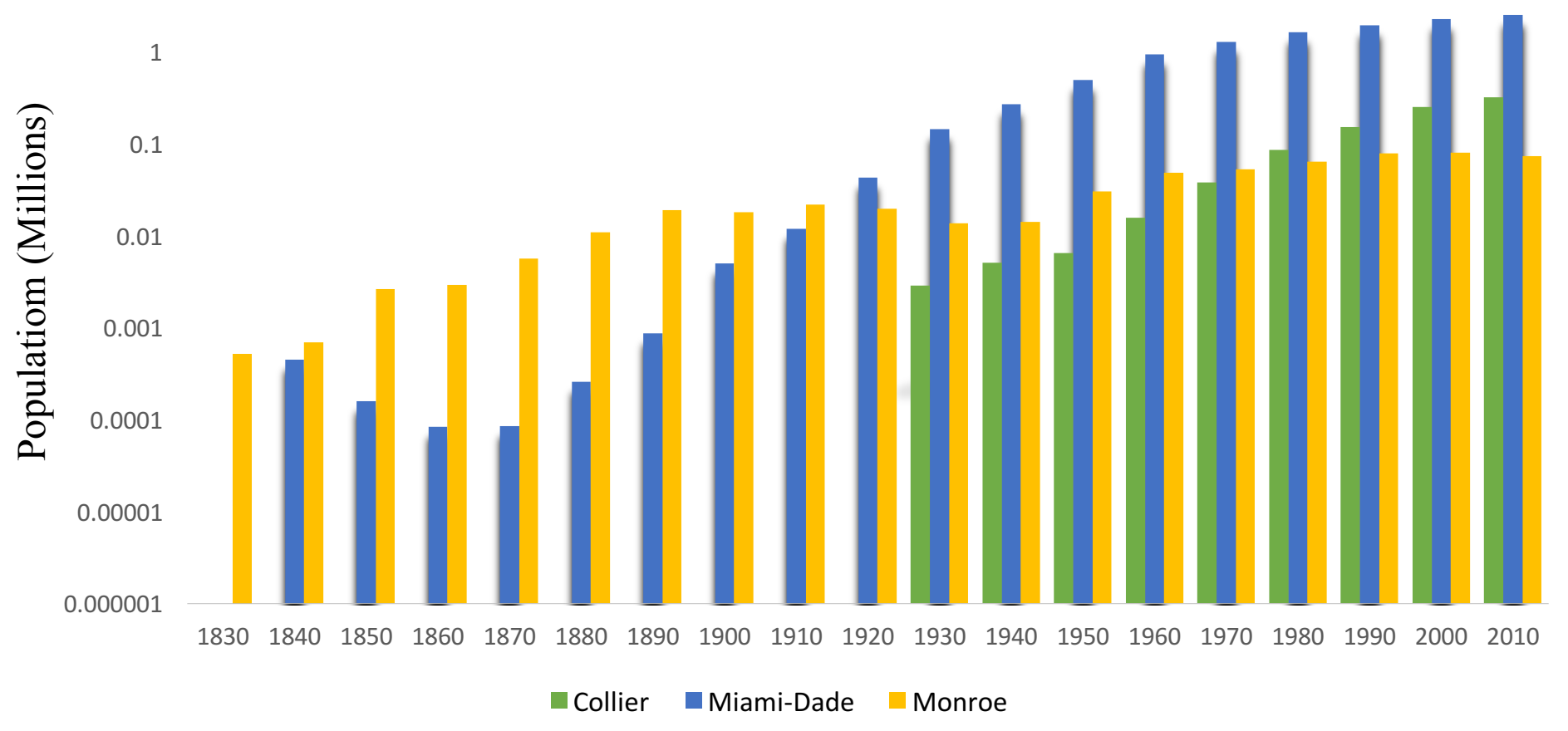

Figure 6. Human population increase for Miami-Dade, Monroe, and Collier counties for the decades of 1830-2010. 


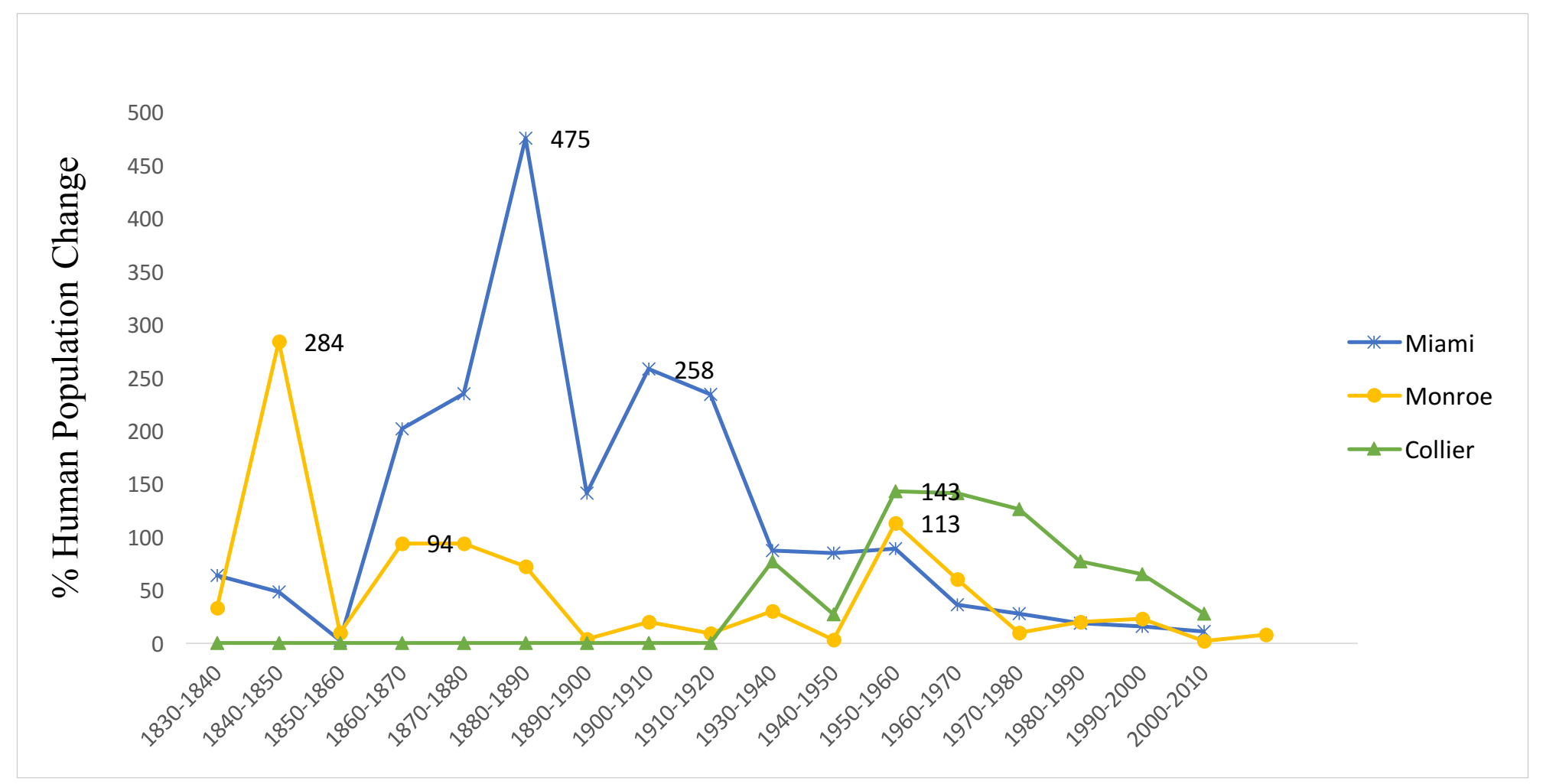

Figure 7. Human population rates of increase for Miami-Dade, Monroe, and Collier counties for the decades of 1830-2010. 


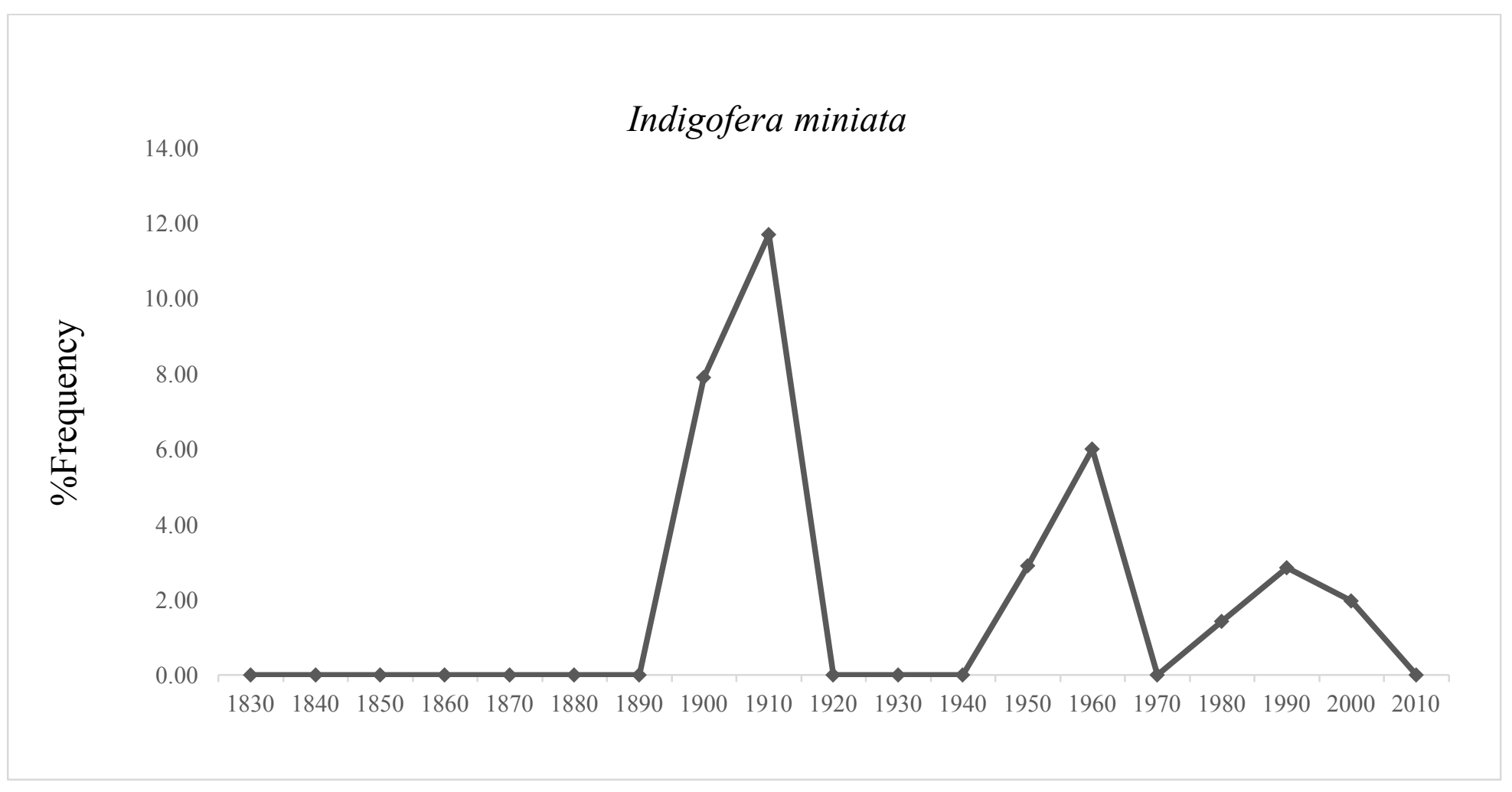

Figure 8. Proportional collection frequency for I. miniata from 1830-2010. 


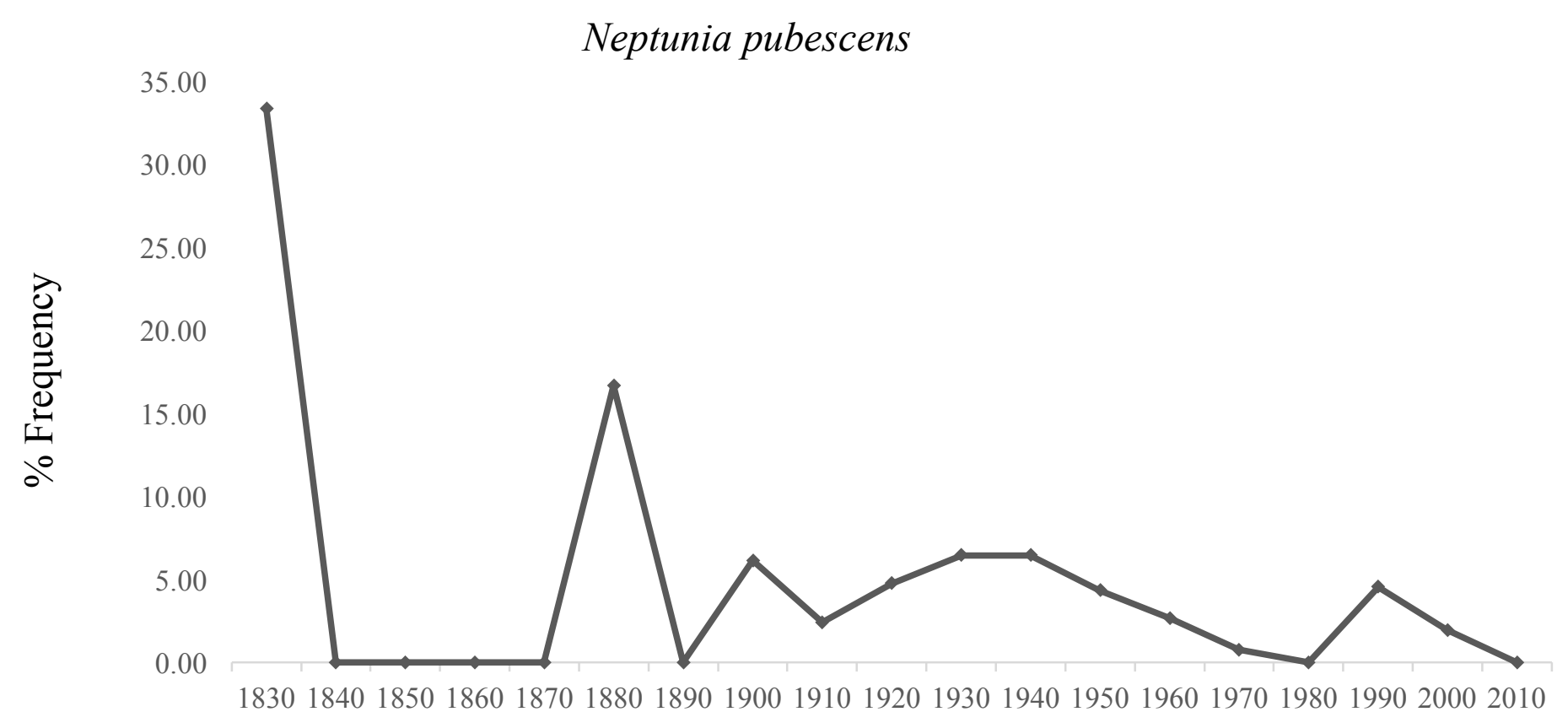

Figure 9. Proportional collection frequency for $N$. pubescens from 1830-2010. 


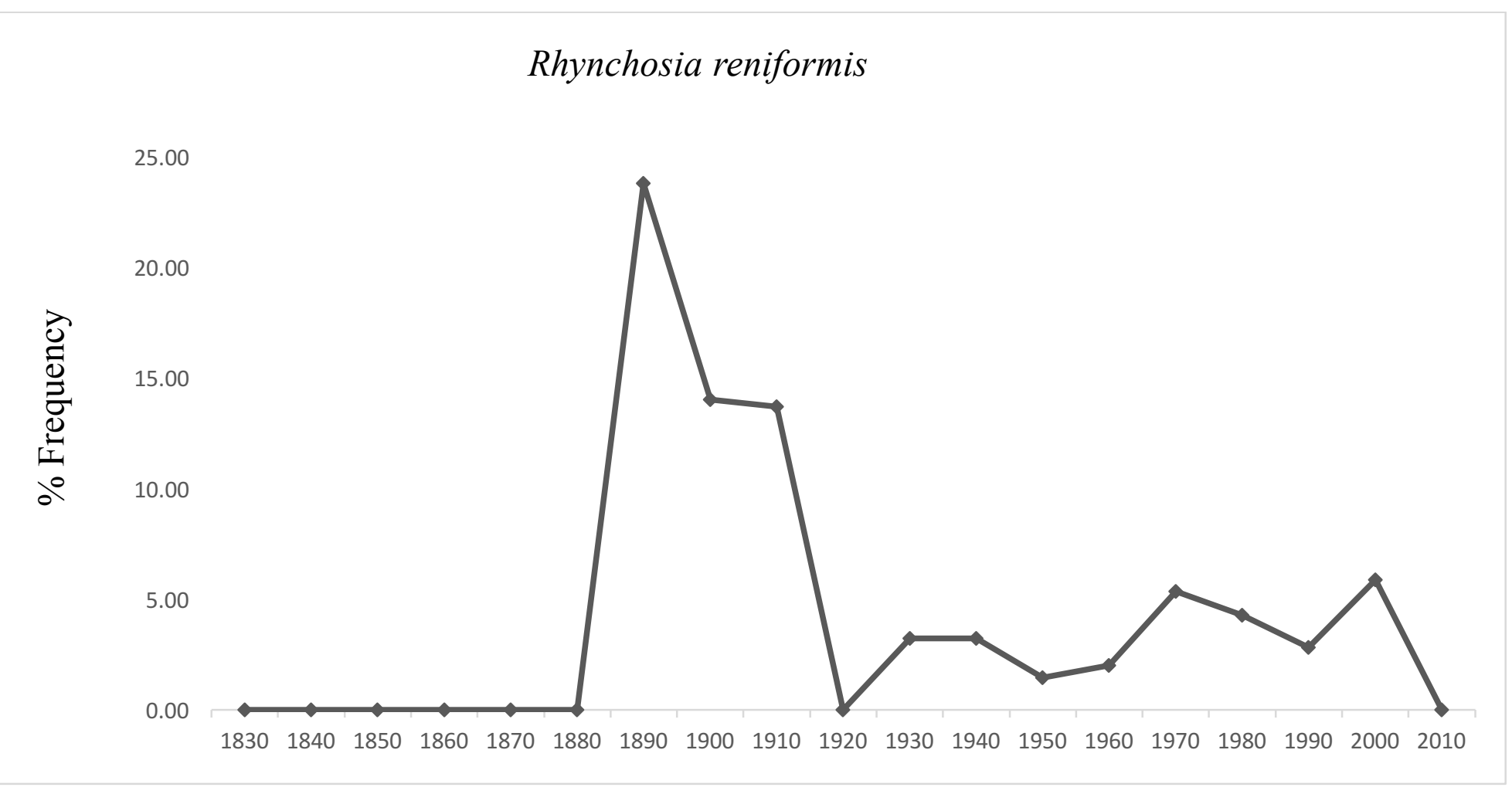

Figure 10. Proportional collection frequency for $R$. reniformis from 1830-2010. 


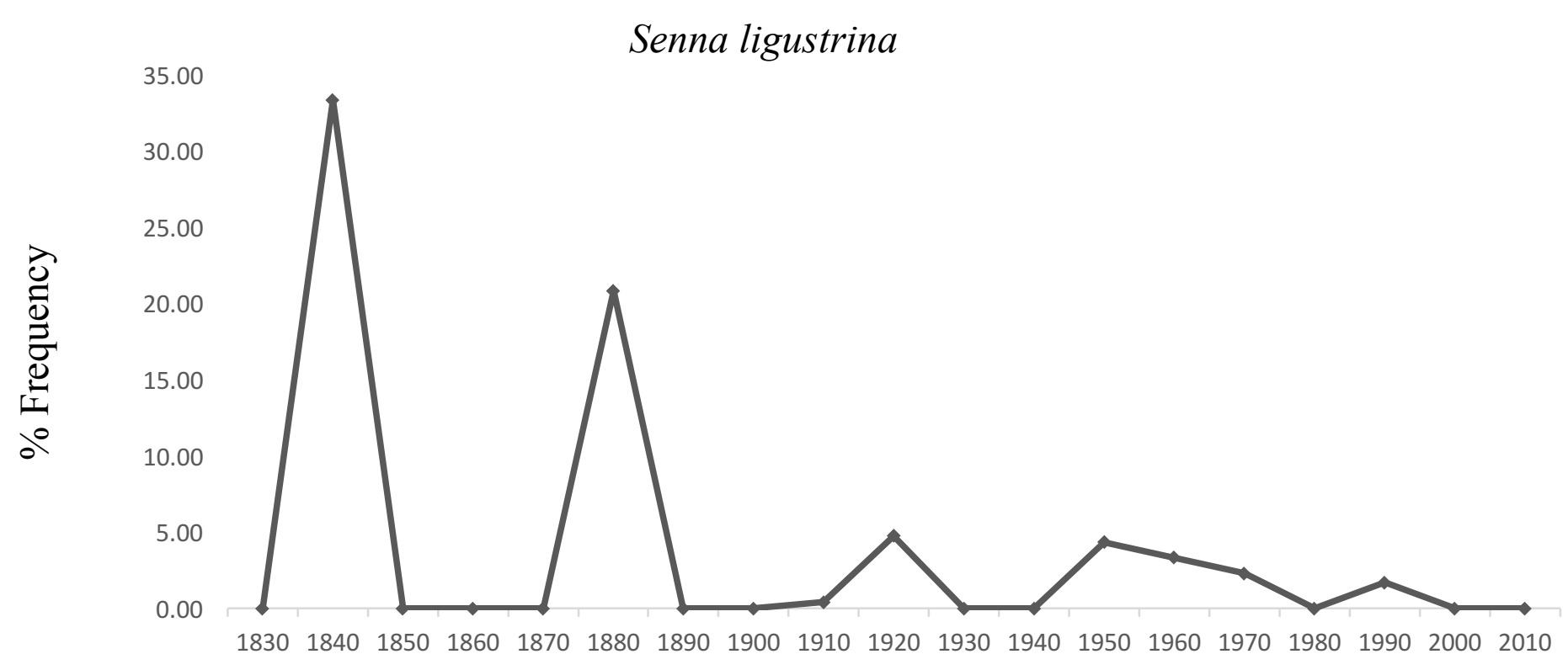

Figure 11. Proportional collection frequency for $S$. ligustrina from 1830-2010. 


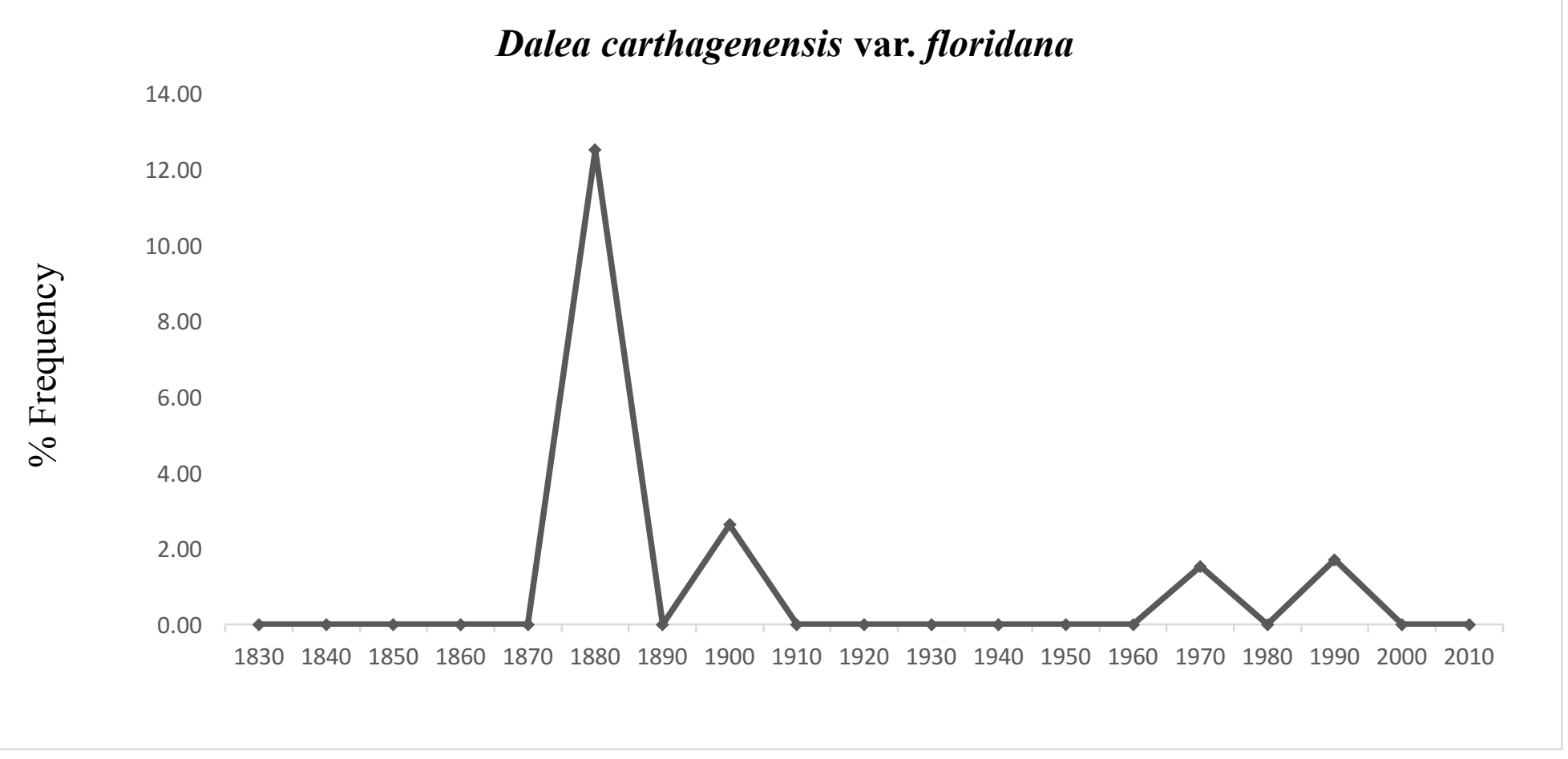

Figure 12. Proportional collection frequency for $D$. carthagenensis var. floridana from 1830-2010. 


\section{REFERENCES}

Alexander, T. R. 1953. Plant Succession on Key Largo, Florida, Involving Pinus Caribea and Quercus Virginina. Quarterly Journal of the Florida Academy of Sciences 16:133-138.

Azani, N., M. Babineau, C. D. Bailey, H. Banks, A. R. Barbosa, R. B. Pinto, J. S. Boatwright, L. M. Borges, G. K. Brown, and A. Bruneau. 2017. A new subfamily classification of the Leguminosae based on a taxonomically comprehensive phylogeny The Legume Phylogeny Working Group (LPWG). Taxon 66:44-77.

Bennett, B. 2011. Twenty-five economically important plant families. Encyclopedia of Life Support Systems :.

Bingham, M. T. 1948. Miami: A Study in Urban Geography. Tequesta 8:73-107.

Bradley, K. A., and S. Saha. 2009. Post-hurricane responses of rare plant species and vegetation of pine rocklands in the lower Florida Keys. Institute for Regional Conservation Miami, .

Brown, J. H. 1984. On the relationship between abundance and distribution of species. The American Naturalist 124:255-279.

Carlton, J. 1953. Building the overseas railway to Key West. Tequesta :3-22.

Chocholoušková, Z., and P. Pyšek. 2003. Changes in composition and structure of urban flora over 120 years: a case study of the city of Plzeň. Flora - Morphology, Distribution, Functional Ecology of Plants 198:366-376.

Coile, N. C. 2002. Native plant? Wildflower? Endemic? Exotic? Invasive? Rare? Endangered?:.

Correll, D. S., H. B. Correll, and H. B. j. a. Correll. 1982. Flora of the Bahama archipelago : (including the Turks and Caicos Islands). J. Cramer, Vaduz.

Dambaugh, L. N. 1962. Land Use in Dade County, Florida. Quarterly Journal of the Florida Academy of Sciences 25:29-44.

Dickson, J. D., R. O. Woodbury, and T. R. Alexander. 1953. CHECK LIST OF FLORA OF BIG PINE KEY, FLORIDA AND SURROUNDING KEYS. Quarterly Journal of the Florida Academy of Sciences 16:181-197.

Dolan, R. W., M. E. Moore, and J. D. Stephens. 2011. Documenting effects of urbanization on flora using herbarium records.(Report). The Journal of Ecology 99:1055. 
Folk, M. L., W. Klimstra, and C. Kruer. 1991. Habitat evaluation: national key deer range. Final report, under review.Florida Game and Fresh Water Fish Commission Nongame Wildlife Program :.

Fuentes, N., E. Ugarte, I. Kühn, and S. Klotz. 2008. Alien plants in Chile: inferring invasion periods from herbarium records. Biological Invasions 10:649.

Gagnon, E., A. Bruneau, C. E. Hughes, L. P. de Queiroz, and G. P. Lewis. 2016. A new generic system for the pantropical Caesalpinia group (Leguminosae). PhytoKeys :1160.

Gann, G.D., and Collaborators. 2001-2015. Floristic Inventory of South Florida Database Online. The Institute for Regional Conservation. Delray Beach, Florida.

Gann, G. D., S. W. Woodmansee, and K. A. Bradley. 2002. Rare plants of south Florida: their history, conservation and restoration. Institute for Regional Conservation, .

Gao, T., H. Yao, J. Song, C. Liu, Y. Zhu, X. Ma, X. Pang, H. Xu, and S. Chen. 2010. Identification of medicinal plants in the family Fabaceae using a potential DNA barcode ITS2. Journal of ethnopharmacology 130:116-121.

Garcillán, P. P., and E. Ezcurra. 2011. Sampling procedures and species estimation: testing the effectiveness of herbarium data against vegetation sampling in an oceanic island. Journal of Vegetation Science 22:273-280.

Geiger, J. H., A. W. Meerow, C. Lewis, R. Oviedo, and J. Francisco-Ortega. 2014. Genetic diversity and conservation of Ipomoea microdactyla (Convolvulaceae): an endemic vine from the Bahamas, Cuba, and southeastern Florida. Plant Species Biology 29:2-15.

Harada, S. 2005. The broad anti-viral agent glycyrrhizin directly modulates the fluidity of plasma membrane and HIV-1 envelope. The Biochemical journal 392:191-199.

Hedenäs, L., I. Bisang, A. Tehler, M. Hamnede, K. Jaederfelt, and G. Odelvik. 2002. A herbarium-based method for estimates of temporal frequency changes: mosses in Sweden. Biological Conservation 105:321-331.

Isley, D. 1990. Vascular Flora of the Southeastern United States: Leguminosae (Fabaceae), Vol. 3 Part 2. :.

Jones, I. M., and S. Koptur. 2015. Dynamic Extrafloral Nectar Production: the Timing of Leaf Damage Affects the Defensive Response in Senna Mexican a Var. Chapmanii (Fabaceae). American Journal of Botany 102:58-66. 
Knapp, S., I. Kühn, J. Stolle, and S. Klotz. 2010. Changes in the functional composition of a Central European urban flora over three centuries. Perspectives in Plant Ecology, Evolution and Systematics 12:235-244.

Koptur, S., I. M. Jones, and J. E. Peña. 2015. The influence of host plant extrafloral nectaries on multitrophic interactions: an experimental investigation. PloS one 10:e0138157.

Langeland, K. A. 2008. Identification and biology of nonnative plants in Florida's natural areas. IFAS Communication Services, University of Florida, .

Lavoie, C. 2013. Biological collections in an ever changing world: Herbaria as tools for biogeographical and environmental studies. Perspectives in Plant Ecology, Evolution and Systematics 15:68-76.

Legume Phylogeny Working Group. 2013. Legume phylogeny and classification in the 21 st century: progress, prospects and lessons for other species-rich clades. Taxon 62:217-248.

Lewis, G. P., and B. D. Schrire. 2003. Leguminosae or Fabaceae. Advances in legume systematics.Part 10:1-3.

Lodge, T. E. 2010. The Everglades handbook: understanding the ecosystem. Crc Press, .

Long, R. W., and O. j. a. Lakela. 1976. A flora of tropical Florida : a manual of the seed plants and ferns of southern peninsular Florida. Banyan Books, Miami, Fla.

Maguire, J. 1995. Restoration plan for Dade County's pine rocklands following Hurricane Andrew. Dade County Department of Environmental Resources Management.On file at Miami-Dade County Department of Environmental Resources Management, Miami, Fla :.

Moerman, D. E., and G. F. Estabrook. 2006. The botanist effect: counties with maximal species richness tend to be home to universities and botanists. Journal of Biogeography 33:1969-1974.

Nesom, G. 2015. Taxonomy of Galactia (Fabaceae) in the USA. Phytoneuron 42:1-54.

Niinemets, Ü., and J. Peñuelas. 2008. Gardening and urban landscaping: significant players in global change. Trends in Plant Science 13:60-65.

Pemberton, R. W., and H. Liu. 2009. Marketing time predicts naturalization of horticultural plants.(Author abstract)(Report). Ecology 90:69. 
Petersen, F. T., and R. Meier. 2003. Testing species-richness estimation methods on single-sample collection data using the Danish Diptera. Biodiversity \& Conservation 12:667-686.

Possley, J., S. W. Woodmansee, and J. Maschinski. 2008. Patterns of plant composition in fragments of globally imperiled pine rockland forest: effects of soil type, recent fire frequency, and fragment size. Natural Areas Journal 28:379-394.

Powell, D., and J. Maschinski. 2012. Connecting Fragments of the Pine Rockland Ecosystem of South Florida: The Connect to Protect Network. Ecological Restoration $30: 285$

Primack, D., C. Imbres, R. B. Primack, A. J. Miller-Rushing, and P. Del Tredici. 2004. Herbarium specimens demonstrate earlier flowering times in response to warming in Boston. American Journal of Botany 91:1260-1264.

Reichard, S. H., and P. White. 2001. Horticulture as a pathway of invasive plant introductions in the United States: most invasive plants have been introduced for horticultural use by nurseries, botanical gardens, and individuals. Bioscience 51:103113.

Richardson, D. M., P. Pysek, M. Rejmanek, M. G. Barbour, F. D. Panetta, and C. J. West. 2000. Naturalization and Invasion of Alien Plants: Concepts and Definitions. Diversity and Distributions 6:93-107.

Rivers, M. C., L. Taylor, N. A. Brummitt, T. R. Meagher, D. L. Roberts, and E. N. Lughadha. 2011. How many herbarium specimens are needed to detect threatened species? Biological conservation. 144:2541-2547.

Ross, M. S., J. J. O'Brien, and da Silveira Lobo Sternberg, Leonel. 1994. Sea-Level Rise and the Reduction in Pine Forests in the Florida Keys. Ecological Applications 4:144-156.

Saha, S., K. Bradley, M. S. Ross, P. Hughes, T. Wilmers, P. L. Ruiz, and C. Bergh. 2011. Hurricane effects on subtropical pine rocklands of the Florida Keys. Climatic Change 107:169-184.

Small, J. K., and P. A. Rydberg. 1913. Flora of the Southeastern United States: Being Descriptions of the Seed-plants, Ferns and Fern-allies Growing Naturally in North Carolina, South Carolina, Georgia, Florida, Tennessee, Alabama, Mississippi, Arkansas, Louisiana, and in Oklahoma and Texas East of the One Hundredth Meridian. The author, .

Snyder, J. R., A. Herndon, and W. B. Robertson Jr. 1990. South Florida rockland. 
Snyder, J. R., M. S. Ross, S. Koptur, and J. Sah. 2005. Developing ecological criteria for prescribed fire in south Florida pine rockland ecosystems.

Stamp, N. E., and J. R. Lucas. 1990. Spatial patterns and dispersal distances of explosively dispersing plants in Florida sandhill vegetation. The Journal of Ecology :589-600.

Tebeau, C. W., W. Marina, and W. Marina. 1999. A history of Florida. University of Miami Press, Coral Gables, Fla.

Webb, D. 1985. What are the criteria for presuming native status?. Watsonia 15:231-236.

Wunderlin, R. P., and B. F. Hansen. 2011. Guide to the vascular plants of Florida. University Press of Florida, Gainesville, FL. 


\section{APPENDICES}

\section{APPENDIX A: SPECECIES CHECK LIST}

\begin{tabular}{|c|c|c|c|c|}
\hline Name & Nativity & Comon Name & Synonyms & Status \\
\hline Abrus precatorius L. & Invasive & Rosary pea & Abrus abrus & \\
\hline $\begin{array}{l}\text { Acacia auriculiformis } \\
\text { A.Cunn. ex Benth. }\end{array}$ & Invasive & Earleaf acacia & $\begin{array}{l}\text { Racosperma } \\
\text { auriculiforme }\end{array}$ & \\
\hline $\begin{array}{l}\text { Acacia angustissima (Mill.) } \\
\text { Kuntze }\end{array}$ & Native & Prairie acacia & $\begin{array}{l}\text { Acaciella angustissima } \\
\text { (Mill.) Britton \& Rose }\end{array}$ & FLA-E \\
\hline $\begin{array}{l}\text { Aeschynomene pratensis } \\
\text { Small }\end{array}$ & Native & $\begin{array}{l}\text { Meadow } \\
\text { Jointvetch }\end{array}$ & none & $\begin{array}{l}\text { ESA-C, } \\
\text { FLA-E }\end{array}$ \\
\hline $\begin{array}{l}\text { Aeschynomene viscidula } \\
\text { Michx. }\end{array}$ & Native & $\begin{array}{l}\text { Sticky } \\
\text { Jointvetch }\end{array}$ & Secula viscidula & \\
\hline Albizia julibrissin Durazz. & Invasive & Silktree & Acaccia julibrissin & \\
\hline Albizia lebbeck (L.) Benth & Invasive & $\begin{array}{l}\text { Woman's } \\
\text { tongue }\end{array}$ & Acacia lebbeck & \\
\hline $\begin{array}{l}\text { Albizia } \\
\text { lebbekoides (DC.)Benth. }\end{array}$ & Exotic & Indian albizia & Acacia lebbekoides & \\
\hline $\begin{array}{l}\text { Albizia procera(Roxb.) } \\
\text { Benth. }\end{array}$ & Exotic & Tall albizia & Acacia procera & \\
\hline $\begin{array}{l}\text { Alysicarpus vaginalis (L.) } \\
\text { DC. }\end{array}$ & Exotic & $\begin{array}{l}\text { White } \\
\text { moneywort }\end{array}$ & $\begin{array}{l}\text { Alysicarpus vaginalis var. } \\
\text { typicus }\end{array}$ & \\
\hline Amorpha fruticosa $\mathrm{L}$. & Native & $\begin{array}{l}\text { Bastard false } \\
\text { indigo }\end{array}$ & Amorpha curtissii & \\
\hline $\begin{array}{l}\text { Amorpha herbacea var. } \\
\text { crenulata (Rydb.) Isley }\end{array}$ & Endemic & $\begin{array}{l}\text { Miami lead } \\
\text { plant }\end{array}$ & Amorpha crenulata & $\begin{array}{l}\text { IUCN-CE, } \\
\text { ESA- } \\
\text { E,FLA-E }\end{array}$ \\
\hline Bauhinia variegata $\mathrm{L}$. & Invasive & Orchid tree & Phanera variegata & \\
\hline $\begin{array}{l}\text { Caesalpinia pulcherrima } \\
\text { (L.) Sw. }\end{array}$ & Exotic & $\begin{array}{l}\text { Dwarf } \\
\text { poinciana }\end{array}$ & Poinciana pulcherrima & \\
\hline Cajanus cajan(L.) Huth & Exotic & Pigeonpea & Cajanus flavus & \\
\hline $\begin{array}{l}\text { Canavalia brasiliensis Mart. } \\
\text { ex Benth. }\end{array}$ & Exotic & $\begin{array}{l}\text { Brazilian } \\
\text { Jackbean }\end{array}$ & Canavalia caribaea & \\
\hline Canavalia rosea (Sw.) DC. & Native & Baybean & Canavalia maritima & \\
\hline Cassia fistula $\mathrm{L}$. & Exotic & Golden shower & Bactyrylobium fistulum & \\
\hline
\end{tabular}




\begin{tabular}{|c|c|c|c|c|}
\hline $\begin{array}{l}\text { Centrosema virginianum(L.) } \\
\text { Benth. }\end{array}$ & Native & $\begin{array}{l}\text { Spurred } \\
\text { Butterfly pea }\end{array}$ & Bradburya virginiana & \\
\hline Ceratonia siliqua $\mathrm{L}$. & Exotic & Carob & & \\
\hline $\begin{array}{l}\text { Chamaecrista deeringiana } \\
\text { Small \& Pennell }\end{array}$ & Native & $\begin{array}{l}\text { Deering } \\
\text { partridge pea }\end{array}$ & Cassia deeringiana & \\
\hline $\begin{array}{l}\text { Chamaecrista fasciculata } \\
\text { (Michx.) Greene }\end{array}$ & Native & Partridge pea & Cassia chamaecrista & \\
\hline $\begin{array}{l}\text { Chamaecrista lineata var. } \\
\text { keyensis (Pennell) H.S. } \\
\text { Irwin \& Barneby }\end{array}$ & Endemic & $\begin{array}{l}\text { Keys partridge } \\
\text { pea }\end{array}$ & Cassia keyensis & $\begin{array}{l}\text { ESA- } \\
\text { E,FLA-E }\end{array}$ \\
\hline $\begin{array}{l}\text { Chamaecrista nictitans var. } \\
\text { aspera(Muhl. ex Elliott) } \\
\text { H.S. Irwin \& Barneby }\end{array}$ & Native & $\begin{array}{l}\text { Hairy sensitive } \\
\text { pea }\end{array}$ & Cassia simpsonii & \\
\hline Clitoria mariana $\mathbf{L}$. & Native & & & \\
\hline $\begin{array}{l}\text { Clitoria ternatea var. } \\
\text { ternatea } \mathrm{L} \text {. }\end{array}$ & Exotic & $\begin{array}{l}\text { Asian } \\
\text { pigeonwings }\end{array}$ & Clitoria ternatea & \\
\hline Crotalaria incana $\mathrm{L}$. & Exotic & Shakeshake & Crotalaria pubescens & \\
\hline $\begin{array}{l}\text { Crotalaria pallida var. } \\
\text { obovata (G. Don) Polhill }\end{array}$ & Exotic & $\begin{array}{l}\text { Smooth } \\
\text { rattlebox }\end{array}$ & Crotolaria striata & \\
\hline Crotalaria pumila Ortega & Native & Low rattlebox & & \\
\hline Crotalaria retusa $\mathrm{L}$. & Exotic & Rattleweed & Crotalaria chiapensis & \\
\hline $\begin{array}{l}\text { Crotalaria rotundifolia } \\
\text { J.F.Gmel. }\end{array}$ & Native & Rabbitbells & Crotalaria linaria & \\
\hline Crotalaria spectabilis Roth & Exotic & Showy rattlebox & Crotalaria sericea & \\
\hline Crotalaria verrucosa $L$. & Exotic & Blue rattlebox & Crotalaria flexuosa & \\
\hline $\begin{array}{l}\text { Dalbergia sissoo Roxb. ex } \\
\text { DC. }\end{array}$ & Invasive & $\begin{array}{l}\text { Indian } \\
\text { rosewood }\end{array}$ & Amerimnom sissoo & \\
\hline Dalea carnea (Michx.)Poir. & Native & Whitetassels & Kuhnistera cranea & \\
\hline $\begin{array}{l}\text { Dalea carthagenensis var. } \\
\text { floridana (Rydb.) Barneby }\end{array}$ & Endemic & $\begin{array}{l}\text { Florida } \\
\text { prairieclover }\end{array}$ & Parosela floridana & $\begin{array}{l}\text { ESA-C, } \\
\text { FLA-E }\end{array}$ \\
\hline $\begin{array}{l}\text { Dalea feayi (Chapm.) } \\
\text { Barneby }\end{array}$ & Native & $\begin{array}{l}\text { Feay's } \\
\text { Prairieclover }\end{array}$ & Kunishtera feayi & \\
\hline Delonix regia (Bojer) Raf. & Exotic & Royal poinciana & Poinciana regia & \\
\hline $\begin{array}{l}\text { Denisophytum pauciflorum* } \\
\text { (Griseb.)Gagnon \& } \\
\text { G.P.Lewis }\end{array}$ & Native & $\begin{array}{l}\text { Fewflower } \\
\text { holdback }\end{array}$ & Caesalpinia pauciflora & FLA-E \\
\hline
\end{tabular}




\begin{tabular}{|c|c|c|c|c|}
\hline $\begin{array}{l}\text { Desmanthus } \\
\text { virgatus (L.)Willd. }\end{array}$ & Native & Wild Tantan & $\begin{array}{l}\text { Acacia } \\
\text { agustisiliqua(Lam.) Desf. }\end{array}$ & \\
\hline $\begin{array}{l}\text { Desmodium ciliare(Muhl. ex } \\
\text { Willd.) DC. }\end{array}$ & Native & $\begin{array}{l}\text { Hairy smallleaf- } \\
\text { ticktrefoil }\end{array}$ & $\begin{array}{l}\text { Meibomia ciliare (Willd.) } \\
\underline{\text { S.F.Blake }}\end{array}$ & \\
\hline $\begin{array}{l}\text { Desmodium } \\
\text { floridanum Chapm. }\end{array}$ & Native & $\begin{array}{l}\text { Florida } \\
\text { Ticktrefoil }\end{array}$ & $\begin{array}{l}\text { Meibomia floridana } \\
\text { (Chapm.) Kuntze }\end{array}$ & \\
\hline Desmodium incanum DC. & Native & Zarzabacoa & $\begin{array}{l}\text { Aeschynomene incana ( } S \\
\text { w.) G.Mey. }\end{array}$ & \\
\hline Desmodium lineatum DC. & Native & Sand ticktrefoil & Meibomia arenicola Vail & \\
\hline $\begin{array}{l}\text { Desmodium marilandicum } \\
\text { (L.) DC. }\end{array}$ & Native & $\begin{array}{l}\text { Smooth } \\
\text { ticktrefoil }\end{array}$ & $\begin{array}{l}\text { Meibomia marilandicum } \\
\text { (L.) DC. }\end{array}$ & \\
\hline $\begin{array}{l}\text { Desmodium rigidum } \\
\text { (Elliott) DC. }\end{array}$ & Native & Stiff ticktrefoil & $\begin{array}{l}\text { Desmodium obtusum } \\
\text { (Muhl. ex Willd.) DC. }\end{array}$ & \\
\hline $\begin{array}{l}\text { Desmodium scorpiurus } \\
\text { (Sw.) Desv. }\end{array}$ & Exotic & $\begin{array}{l}\text { Scorpion } \\
\text { ticktrefoil }\end{array}$ & $\begin{array}{l}\text { Hedysarum scorpiurus } \\
\text { Sw. }\end{array}$ & \\
\hline $\begin{array}{l}\text { Desmodium strictum } \\
\text { (Pursh) DC. }\end{array}$ & Native & $\begin{array}{l}\text { Pinebarren } \\
\text { ticktrefoil }\end{array}$ & $\begin{array}{l}\text { Meibomia stricta (Pursh) } \\
\text { Kuntze }\end{array}$ & \\
\hline $\begin{array}{l}\text { Desmodium } \\
\text { tortuosum (Sw.) DC. }\end{array}$ & Exotic & Dixie tictrefoil & $\begin{array}{l}\text { Meibomia tortuosa (Sw.) } \\
\text { Kuntze }\end{array}$ & \\
\hline $\begin{array}{l}\text { Desmodium triflorum (L.) } \\
\text { DC. }\end{array}$ & Exotic & $\begin{array}{l}\text { Threeflower } \\
\text { ticktrefoil }\end{array}$ & $\begin{array}{l}\text { Meibomia triflora }(\mathrm{L} .) \\
\text { Kuntze }\end{array}$ & \\
\hline Erythrina herbacea (L.) & Native & Coralbean & Erythrina arborea Small & \\
\hline Galactia elliottii Nutt. & Native & Elliott's milkpea & & \\
\hline Galactia parvifolia A. Rich. & Native & $\begin{array}{l}\text { Small leaf } \\
\text { milkpea }\end{array}$ & Galactia grisebachii Urb. & \\
\hline $\begin{array}{l}\text { Galactia floridana Torr. \& } \\
\text { A. Gray }\end{array}$ & Native & Hairy milkpea & Galactia fasciculata Vail & \\
\hline Galactia pinetorum Small & Endemic & $\begin{array}{l}\text { Pinerockland } \\
\text { milkpea }\end{array}$ & & \\
\hline $\begin{array}{l}\text { Galactia regularis (L.) } \\
\text { Britton, Sterns \& Poggenb. }\end{array}$ & Native & Eastern milkpea & Dolichos regularis & \\
\hline $\begin{array}{l}\text { Galactia smallii H.J. Rogers } \\
\text { ex Herndon }\end{array}$ & Endemic & Small's milkpea & Galactia prostrate Small & $\begin{array}{l}\text { ESA- } \\
\text { E,FLA-E }\end{array}$ \\
\hline Galactia striata (Jacq.)Urb. & Native & $\begin{array}{l}\text { Florida } \\
\text { hammock } \\
\text { milkpea }\end{array}$ & $\begin{array}{l}\text { Galactia spiciformis } \\
\text { Torrey \& A. Gray }\end{array}$ & \\
\hline $\begin{array}{l}\text { Galactia volubilis } \\
\text { (L.)Britton }\end{array}$ & Native & Downy mikpea & $\begin{array}{l}\text { Galactia macreei } \\
\text { Galactia macreei }\end{array}$ & \\
\hline
\end{tabular}




\begin{tabular}{|c|c|c|c|}
\hline Guilandina bonduc L.* & Native & Gray nicker & $\begin{array}{l}\text { Caesalpinia bonduc (L.) } \\
\text { Roxb. }\end{array}$ \\
\hline Indigofera caroliniana Mill. & Native & Carolina indigo & Indigofera disperma $\mathrm{L}$. \\
\hline Indigofera hirsute $\mathrm{L}$. & Exotic & Hairy indigo & Anila hirsute (L.) Kuntze \\
\hline Indigofera miniata Ortega & Native & Coastal indigo & $\begin{array}{l}\text { Indigofera miniata } \\
\text { var.florida Isely }\end{array}$ \\
\hline Indigofera spicata Forssk. & Exotic & Trailing indigo & $\begin{array}{l}\text { Anila spicata (Forsskål) } \\
\text { Kuntze }\end{array}$ \\
\hline Indigofera suffruticosa Mill. & Exotic & Anilde pasto & \\
\hline $\begin{array}{l}\text { Kummerowia striata } \\
\text { (Thunb.)Schindl. }\end{array}$ & Exotic & Japanese clover & $\begin{array}{l}\text { Desmodium striatum } \\
\text { (Thunb.) DC. }\end{array}$ \\
\hline $\begin{array}{l}\text { Leucaena leucocephala } \\
\text { (Lam.)de Wit }\end{array}$ & Invasive & White leadtree & $\begin{array}{l}\text { Acacia leucocephala } \\
\text { (Lam.) Link }\end{array}$ \\
\hline $\begin{array}{l}\text { Lysiloma latisiliquum } \\
\text { (L.)Benth. }\end{array}$ & Native & Wild tamarind & $\begin{array}{l}\text { Acacia bahamensis } \\
\text { (Bentham) Grisebach }\end{array}$ \\
\hline Lysiloma sabicu Benth. & Exotic & $\begin{array}{l}\text { Horseflesh } \\
\text { mahogany }\end{array}$ & Acacia fomosa Kunth \\
\hline $\begin{array}{l}\text { Macroptilium } \\
\text { gibbosifoliu(Ortega) A. } \\
\text { Delgado }\end{array}$ & Exotic & Wild bushbean & $\begin{array}{l}\text { Phaseolus heterophyllus } \\
\text { Willd. }\end{array}$ \\
\hline $\begin{array}{l}\text { Macroptilium lathyroides } \\
\text { (L.)Urb. }\end{array}$ & Invasive & Wild bushbean & Phaseolus lathyroides L. \\
\hline Melilotus albus Medik. & Exotic & $\begin{array}{l}\text { White } \\
\text { sweetclover }\end{array}$ & $\begin{array}{l}\text { Medicago alba (Medikus) } \\
\text { Krause }\end{array}$ \\
\hline Mimosa pudica $\mathbf{L}$. & Exotic & Sensitive plant & \\
\hline $\begin{array}{l}\text { Mimosa quadrivalvis var. } \\
\text { angustata (Torr. \& } \\
\text { A.Gray)Barneby }\end{array}$ & Native & Sensitive brier & Mimosa horridula Michx. \\
\hline Mucuna pruriens (L.)DC. & Exotic & Velvetbean & Dolichos pruriens L. \\
\hline Neptunia pubescens Benth. & Native & Tropical puff & Neptunia floridana Small \\
\hline Pachyrhizus erosus (L.)Urb. & Exotic & Yam bean & Cacara erosa L. \\
\hline Parkinsonia aculeata $\mathrm{L}$. & Exotic & Jerusalem thorn & Parkinsoni spinosa Kunth \\
\hline Phaseolus lunatus L. & Exotic & Lima bean & \\
\hline $\begin{array}{l}\text { Phaseolus polystachios var. } \\
\text { sinuatus (Nutt. ex Torr. \& } \\
\text { A. Gray) R. Marechal, J.M. } \\
\text { Mascherpa \& F. Stainier }\end{array}$ & Native & Thicket bean & $\begin{array}{l}\text { Phaseolus sinuatus Nutt. } \\
\text { ex Torr. \& A. Gray }\end{array}$ \\
\hline
\end{tabular}




\begin{tabular}{|c|c|c|c|c|}
\hline Phaseolus vulgaris L. & Exotic & Kidney bean & & \\
\hline Piscidia piscipula (L.) Sarg. & Native & Fishpoison tree & Piscidia erythrina $\mathrm{L}$. & \\
\hline $\begin{array}{l}\text { Pithecellobium bahamense } \\
\text { Northrop }\end{array}$ & Native & & & \\
\hline $\begin{array}{l}\text { Pithecellobium dulce } \\
\text { (Roxb.)Benth. }\end{array}$ & Exotic & Monkeypod & & \\
\hline $\begin{array}{l}\text { Pithecellobium keyense } \\
\text { Britton ex Britton \& Rose }\end{array}$ & Native & $\begin{array}{l}\text { Florida Keys } \\
\text { blackbead }\end{array}$ & & \\
\hline $\begin{array}{l}\text { Pithecellobium unguis- } \\
\text { cati (L.) Benth. }\end{array}$ & Native & $\begin{array}{l}\text { Catclaw } \\
\text { blackbead }\end{array}$ & & \\
\hline $\begin{array}{l}\text { Pueraria montana var. lobat } \\
\text { a (Willd.) Maesen \& S.M. } \\
\text { Almeida ex Sanjappa \& } \\
\text { Predeep }\end{array}$ & Invasive & Kudzu & & \\
\hline Rhynchosia cinerea Nash & Native & $\begin{array}{l}\text { Brownhair } \\
\text { snoutbean }\end{array}$ & $\begin{array}{l}\text { Dolicholus cinereus } \\
\text { (Nash) Vail }\end{array}$ & \\
\hline Rhynchosia michauxii Vail & Native & $\begin{array}{l}\text { Michaux's } \\
\text { snoutbean }\end{array}$ & $\begin{array}{l}\text { Dolicholus michauxii } \\
\text { (vail) Vail }\end{array}$ & \\
\hline Rhynchosia minima (L.)DC. & Native & Least snoubean & $\begin{array}{l}\text { Dolicholus minimus (L.) } \\
\text { Medik. }\end{array}$ & IUCN-LC \\
\hline Rhynchosia parvifolia DC. & Native & $\begin{array}{l}\text { Small leaf } \\
\text { snoutbean }\end{array}$ & & \\
\hline Rhynchosia reniformis DC. & Native & Dollarleaf & $\begin{array}{l}\text { Dolicholus simplicifolius } \\
\text { (Walter) Vail }\end{array}$ & FLA-T \\
\hline $\begin{array}{l}\text { Senna ligustrina } \\
\text { (L.)H.S.Irwin \& Barneby }\end{array}$ & Native & $\begin{array}{l}\text { Privet wild } \\
\text { sensitive plant }\end{array}$ & Cassia bahamensis Mill. & \\
\hline $\begin{array}{l}\text { Senna mexicana var. } \\
\text { chapmanii (Isely) H.S. } \\
\text { Irwin \& Barneby }\end{array}$ & Native & $\begin{array}{l}\text { Chapman's wild } \\
\text { sensitive plant }\end{array}$ & Cassia chapmanii Isely & FLA-T \\
\hline $\begin{array}{l}\text { Senna obtusifolia } \\
\text { (L.)H.S.Irwin \& Barneby }\end{array}$ & Native & Coffeeweed & Cassia obtusifolia L. & \\
\hline Senna occidentalis (L.) Link & Exotic & Septicweed & Cassia occidentalis (L.) & \\
\hline $\begin{array}{l}\text { Senna pendula var. } \\
\text { glabrata (Vogel) H.S. Irwin } \\
\text { \& Barneby }\end{array}$ & Invasive & Valamuerto & $\begin{array}{l}\text { Cassia coluteoides } \underline{\text { Colla }} \\
\underline{\text { d. }}\end{array}$ & \\
\hline $\begin{array}{l}\text { Senna surattensis } \\
\text { (Burm.f.)H.S.Irwin \& } \\
\text { Barneby }\end{array}$ & Exotic & Glossy shower & & \\
\hline
\end{tabular}




\begin{tabular}{|c|c|c|c|c|}
\hline $\begin{array}{l}\text { Sesbania herbacea } \\
\text { (Mill.)McVaugh }\end{array}$ & Native & Danglepod & $\begin{array}{l}\text { Sesbania emerus (Aubl.) } \\
\text { Urb. }\end{array}$ & \\
\hline $\begin{array}{l}\text { Sesbania vesicaria } \\
\text { (Jacq.)Elliott }\end{array}$ & Native & Bagpod & $\begin{array}{l}\text { Glottidium vesicarium (J } \\
\text { acq.) R.M. Harper }\end{array}$ & \\
\hline $\begin{array}{l}\text { Sophora tomentosa var. } \\
\text { truncata Torr. \& A.Gray }\end{array}$ & Native & $\begin{array}{l}\text { Yellow } \\
\text { necklacepod }\end{array}$ & & \\
\hline $\begin{array}{l}\text { Stylosanthes } \\
\text { biflora (L.)Britton et al. }\end{array}$ & Native & $\begin{array}{l}\text { Sidebeak } \\
\text { pencilflower }\end{array}$ & $\begin{array}{l}\text { Stylosanthes floridana S. } \\
\text { F. Blake }\end{array}$ & \\
\hline Stylosanthes calcicola Small & Native & $\begin{array}{l}\text { Everglades Key } \\
\text { Pencilfower }\end{array}$ & & FLA-E \\
\hline $\begin{array}{l}\text { Stylosanthes hamata } \\
\text { (L.)Taub. }\end{array}$ & Native & Cheesytoes & & \\
\hline Tamarindus indica $\mathrm{L}$. & Exotic & Tamarind & & \\
\hline $\begin{array}{l}\text { Tephrosia angustissima } \\
\text { Shuttlew. ex Chapm. }\end{array}$ & Endemic & $\begin{array}{l}\text { Narrowleaf } \\
\text { hoarypea }\end{array}$ & $\begin{array}{l}\text { Cracca angustissima } \\
\text { (Shuttleworth ex } \\
\text { Chapman) Kuntze }\end{array}$ & $\begin{array}{l}\text { IUCN-E, } \\
\text { FLA-E }\end{array}$ \\
\hline $\begin{array}{l}\text { Tephrosia florida } \\
\text { (F.Dietr.)C.E.Wood }\end{array}$ & Native & $\begin{array}{l}\text { Florida } \\
\text { hoarypea }\end{array}$ & $\begin{array}{l}\text { Cracca ambigua (M. A. } \\
\text { Curtis) Kuntze }\end{array}$ & \\
\hline $\begin{array}{l}\text { Tephrosia spicata } \\
\text { (Walter)Torr. \& A.Gray }\end{array}$ & Native & Spike hoarypea & $\begin{array}{l}\text { Cracca flexuosa (Vail) A. } \\
\text { Heller }\end{array}$ & \\
\hline Trifolium hybridum $\mathrm{L}$. & Exotic & Alsike clover & $\begin{array}{l}\text { Amoria hybrida (L.) } \\
\text { C.Presl }\end{array}$ & \\
\hline Trifolium repens $\mathbf{L}$. & Exotic & White clover & & \\
\hline $\begin{array}{l}\text { Vachellia choriophylla } \\
\text { (Benth.)Seigler \& Ebinger }\end{array}$ & Native & Cinnecord & $\begin{array}{l}\text { Acacia choriophylla } \\
\text { Bentham }\end{array}$ & FLA-E \\
\hline $\begin{array}{l}\text { Vachellia } \\
\text { cornigera }\left(\mathrm{L}_{.}\right) \text {Seigler \& } \\
\text { Ebinger }\end{array}$ & Exotic & Bullhorn acacia & Acacia cornigera L. & \\
\hline $\begin{array}{l}\text { Vachellia farnesiana var. } \\
\text { farnesiana (L.) Wight \& } \\
\text { Arn. }\end{array}$ & Native & Sweet acacia & $\begin{array}{l}\text { Acacia farnesiana } \\
\text { (Linnaeus) Willdenow }\end{array}$ & \\
\hline $\begin{array}{l}\text { Vachellia farnesiana var. } \\
\text { pinetorum (L.) Wight \& } \\
\text { Arn. }\end{array}$ & Native & Pineland acacia & $\begin{array}{l}\text { Acacia pinetorum F. J. } \\
\text { Hermann }\end{array}$ & \\
\hline $\begin{array}{l}\text { Vachellia sphaerocephala } \\
\text { (Schltdl. \& Cham.) Seigler } \\
\text { \& Ebinger }\end{array}$ & Exotic & Bee wattle & $\begin{array}{l}\text { Acacia sphaerocephala } \underline{\mathrm{S}} \\
\text { chltdl. \& Cham. }\end{array}$ & \\
\hline
\end{tabular}




\begin{tabular}{|c|c|c|c|}
\hline Vicia acutifolia Elliott & Native & Fourleaf vetch & $\begin{array}{l}\text { Cracca acutifolia (Elliott) } \\
\text { Alefeld }\end{array}$ \\
\hline $\begin{array}{l}\text { Vigna adenantha } \\
\text { Vigna adenantha (G. } \\
\text { Mey.) Maréchal, } \\
\text { Mascherpa \& Stainier }\end{array}$ & Exotic & Wild pea & $\begin{array}{l}\text { Leptospron adenanthum } \\
\text { (G.Mey.)A.Delgado }\end{array}$ \\
\hline Vigna luteola (Jacq.)Benth. & Native & $\begin{array}{l}\text { Hairypod } \\
\text { cowpea }\end{array}$ & Vigna repens (L.) Kuntze \\
\hline $\begin{array}{l}\text { Vigna speciosa (Kunth) } \\
\text { Verdc. }\end{array}$ & Exotic & Prairie vetch & $\begin{array}{l}\text { Phaseolus speciosus } \\
\text { Kunth }\end{array}$ \\
\hline Zornia bracteata J.F.Gmel. & Native & Viperina & $\begin{array}{l}\text { Hedysarum tetraphyllum } \\
\text { Poiret }\end{array}$ \\
\hline
\end{tabular}

